한국심리학회지: 산업 및 조직

Korean Journal of Industrial and Organizational Psychology

2021. Vol. 34, No. 3, 511-539

https://doi.org/10.24230/kiop.v34i3.511-539

\title{
한국판 어두운 성격 3요소 단축형의 요인구조와 타당화 지표
}

\author{
박 종철 오현 주 이나희 손하 림 이 동 귀 ${ }^{+}$배 병 훈 \\ 연세대학교
}

\begin{abstract}
본 연구에서는 한국어로 번안된 자기애, 마키아벨리즘, 사이코패스로 구성된 27 문항의 어두 운 성격 3요소 측정도구(the Short Dark Triad: SD3)의 심리측정적 속성(타당도, 신뢰도)을 확인 하였다. 두 개의 연구(연구1 $N=250$, 연구2 $N=250$ )을 통해 각각 탐색적 요인분석과 확인 적 요인분석을 실시한 결과, 한국에서 $\mathrm{SD} 3$ 는 원개발자들이 제안한 3요인 구조가 아닌 2요인 구조자기애, 마키아벨리즘-사이코패스(Ma-Psy)]임을 확인하였다. 또한 문항의 특성을 알아보 기 위해 Rasch모형을 적용하여 문항의 적합도와 난이도를 분석한 결과를 바탕으로 17 개의 문항으로 이루어진 어두운 성격 2 요소 측정도구(SD-2)를 확정하였다. SD-2에 대한 수렴타당 도 및 변별타당도 증거들과 시간적인 안정성(1개월 간격)을 확인하였다. 끝으로 본 연구의 의의 및 제한점을 논의하였다.
\end{abstract}

주요어 : 어두운 성격 3 요소, 자기애, 마키아벨리즘, 사이코패스

† 교신저자 : 이동귀, 연세대학교, 서울시 서대문구 연세로 50 연세대학교 위당관 612호 Tel: 02-2123-2437, E-mail: lee82@yonsei.ac.kr 
최근 가공유업체의 대리점 횡포 사건, 땅콩 회항사건, 기업 대표의 직원 및 운전기사 폭 행사건 등 '갑질 문제'가 우리 사회의 어두운 면을 보여주고 있다(Cho, 2017). 이를 반영하듯 한국의 갑질 문화에 대한 설문조사 결과, 전 체 응답자의 $50 \%$ 가 “매우 심각하다", $46 \%$ 가 "대체로 심각하다"라고 응답했다(Jeong \& Jo, 2019). 갑질 행위는 행위자 자신의 우월성과 타인과의 차별성을 강조하는 특권의식 같은 성격적 특성과 높은 연관성이 있다(Ahn \& $\mathrm{Kim}, 2016)$. 특히, 직장내에서 사회적 지위와 권력을 이용하여 갑질과 같은 비윤리적인 행 위를 저지르는 사람들은 자아도취적이며, 타 인을 조종하는데 능하고 공감능력이 부족한 반사회적인 사이코패스(psychopath)의 성격적 특질을 지닌 경우가 많은 것으로 밝혀졌다 (Babiak, 1995).

이러한 성격에 대해 Paulhus와 Williams(2002) 는 사회적으로 범죄를 저지르거나 임상적 수 준까지는 아니지만 사회적 문제를 일으킬 가 능성이 높은 개인의 성향을 자기애(Narcissism), 마키아벨리즘(Machiavellianism), 사이코패스 (Psychopathy)의 3가지 성격으로 구성된 어두운 성격 3요소(Dark Triad)라 명명하였고, 이후 이 는 서구의 많은 연구자들로부터 주목을 받아 왔다(Zeigler-Hill \& Marcus, 2016). 최근 산업 및 조직 분야에서 어두운 성격 3 요소가 조직에 미치는 부정적인 영향에 대한 연구가 활발히 진행되고 있다. 어두운 성격 3 요소와 관련된 파괴적 행동(예: 비생산적 업무 행동, 학대적 감독)이 조직에 안전과 생산성에 악역향을 끼 칠 수 있으며(Cohen, 2016; Spain et al., 2014), 심리적으로 경쟁적인 조직 환경일수록 어두운 성격이 더욱 과도하게 표출될 수 있다는 연구 결과(Spurk \& Hirschi, 2018)는 조직원 선별과
조직 문화 개선 등의 영역에서 어두운 성격의 3 요소를 파악하는 것이 중요함을 의미한다.

어둠의 성격 3 요소는 심리학에서 연구되는 대표적인 부정적 성격 특성에 속하며. '어두운 (dark)'이라고 말하는 이유는 3가지 성격 모두 공통적으로 냉담함, 공감의 부재, 이중성 등의 악의적인 특징을 갖기 때문이다(Paulhus \& Willims, 2002). 자기애의 뿌리는 13 세기 전 Narcissus 이야기로 거슬러 올라가며, 최근 수 십 년 동안 자기애에 대한 경험적 연구가 진 행되어 왔다(Campbell \& Miller, 2011; Levy et al., 2012). 자기애는 정신장애에 대한 진단 및 통계편람 제5판(Diagnostic and Statistical Manual for Mental Disorders(DSM-5; American Psychiatric Association, 2013)내에서 자기애성 성격장애 (Narcissistic Personality Disorder: NPD)로 대표된 다. 이러한 자기애는 자신 스스로를 과도하게 긍정적으로 평가하는 웅대한 자기상, 자신의 가치를 타인보다 우위에 두는 특권의식, 타인 에 대한 착취, 공감의 결여 등을 특징으로 한 다(Furnham et al., 2013).

마키아벨리즘은 16 세기 메디치 가문의 정치 고문이자 자신의 목표를 달성하기 위한 책략 (策略) 전술을 통해 정치권력을 유지하는 방법 을 설명한 니콜 마키아벨리(Niccolo Machiavelli) 의 저술인 군주론(Il Principle)에서 유래한다. 일부 연구자들은 $\mathrm{BC}$ 6세기경 중국 전국 시대 의 제(齊)나라 병법가 손자의 저서에서도 마키 아벨리가 제안한 전략과 유사한 설명이 포함 되어 있음을 언급한 바 있다(Jones \& Paulhus, 2011). 마키아벨리즘은 도덕성의 결여, 감정적 냉담함, 그리고 높은 수준의 개인적 이익 추 구가 특징이며, 성취동기가 높아 이를 충족하 기 위해 타인을 속이고 조종하고 착취하며, 자신의 이익을 위해 동맹을 구축하고 자신의 
상황에 유리하게 자신의 평판을 재구축하기도 한다(Furnham et al., 2013).

한편, 사이코패스는 19세기 초 프랑스의 정신과의사인 Philippe Pinel이 이를 인지장애 의 명백한 징후 없이 도덕적으로 의심스럽고 일탈적인 행동을 하는 개인으로 묘사하기 위 해 망상 증세가 없는 미치광이(mania without delirium)'로 표현하였고 Cleckley(1941)가 정신병 적 성격에 대한 사례 연구를 요약한 '이성의 가면(Mask of Sanity)'에서 언급한 바 있다(Lyons, 2019, pp. 12). 사이코패스는 지속적인 반사회 적 행동, 죄책감 - 후회 · 공감의 결여, 충동성, 자기중심성 등을 특징으로 한다(Furnham et al., 2013).

어두운 성격의 3 가지 요소들은 각각 차별적 인 특징을 보이기는 하나 공통적인 특성을 보 인다(Jonason et al., 2011; Paulhus \& Williams, 2002). 이는 타인에 대한 냉담함에서 비롯되며 (Jones \& Paulhus, 2011), 어두운 성격 3요소가 왜 사회적으로 부정적인 평판을 가지게 되는 지에 대한 설명이 가능케 한다. 즉, 어두운 성 격 3요소의 공통 성격 중 냉담함(공감의 결여) 는 필연적으로 다른 사람을 조종하는 경향으 로 이어지고(Paulhus \& Jones, 2015), 이러한 성 격 특성을 가진 사람들은 단기적인 타인과의 상호작용 상황에서는 매력적인 인상을 주기도 하지만, 장기적인 타인과의 상호작용에서는 낮은 공감 능력 및 자신의 이익만을 추구하는 착취적인 행동 등으로 인해 타인으로부터 부 정적인 평가를 받게 된다(Rauthman \& Kolar, 2012).

어두운 성격 3 요소에 대한 측정도구로는 3 요소를 개별적으로 측정하는 도구와 3 요소를 동시에 측정할 수 있는 도구가 있다. 우선 개 별적으로 측정하는 도구들을 살펴보면 자기애
를 측정하는 도구에는 Narcissistic Personality Inventory(NPI; Raskin \& Hall, 1981), Narcissistic Admiration and Rivalry Questionnaire(Back et al., 2013), Communal Narcissism Inventory(Gebauer et al., 2012)가 있고 이 중에서 가장 많이 사용 되는 NPI의 경우 40 문항으로 구성되어 있다. 마키아벨리즘을 측정하는 도구에는 Trimmed MACH(Rauthmann, 2013), Mach VI(Christie \& Geis, 1970), Machiavellian Personality Scale(MPS; Dahling et al., 2009)이 있고 MPS는 45 문항으로 구성되어 있다. 마지막으로 사이코패스에서 널리 사용되는 척도에는 64 개 항목으로 구성 된 SRP-III척도(Mahmut et al., 2011; Williams et al., 2007)와 100 개 이상의 항목으로 구성된 Psychopathic Personality Inventory-Revised(Lilienfeld \& Andrews, 1996)가 존재한다.

자기보고 설문을 실시할 경우 문항이 많아 지면 수검자의 피로도가 높아져 불성실한 반 응을 불러 일으켜 검사 결과에 영향을 줄 수 있다. 특히 어두운 성격의 3 요소의 경우 3 개 의 성격을 각각의 척도로 측정하기 위해서는 많은 문항들에 답해야 하는 불편함이 있었다. 이러한 한계점을 보완하기 위해서 어두운 성 격 3요소 측정을 위한 보다 간단한 도구들이 개발되었다. 먼저 Jonason과 Webster(2010)는 12 문항으로 구성된 Dirty Dozen(DD)을 개발하였 다. 그러나 척도 문항을 단축하는 과정에서 일부 필수 요소를 제거함으로써 각 요소들 간 에 관련성이 약하다는 단점이 있다(Miller et al., 2012). 아울러, $\mathrm{DD}$ 는 3요인 구조라기보다 2요인 구조일 수 있다는 점이 제안되었는데 (Kajonius et al., 2016; Miller et al., 2016), 이는 특히 마키아벨리즘과 사이코패스가 다른 사람 에 대한 착취와 냉담함을 보인다는 공통적인 특성을 나타내기 때문이다. 
Jones와 Paulhus(2014)는 어두운 성격 3요소 차원이 비슷하지만 서로 다른 심리적 현상을 반영한다는 점을 토대로 간단하게 측정할 수 있는 어두운 성격 3 요소 측정도구(the Short Dark Triad: SD3)를 개발하였다. SD3는 세 개 의 하위 요인 당 각각 9 개 문항, 총 27 개의 문항으로 구성되어 있으며, 자기애는 리더십 (Leadership), 과시옥(Exhibitionism), 웅대한 자기 상(Grandiosity), 자기가치부여(Entitlement)를 마 키아벨리즘은 평판(Reputation), 냉소(Cynicism), 동맹구축(Coalition Building), 계획(Planning)을 사 이코패스는 반사회적 행동(Antisocial Behavior), 불규칙한 생활방식(Erratic Life style), 무감각 감정(Callous Affect), 단기속임수(Short-term Manipulation)의 측면을 측정한다. $\mathrm{SD} 3$ 는 미국, 캐나다 등 다양한 국적의 표본을 대상으로 양 호한 수렴 및 변별 타당도와 문항간 내적 일 관성(Jones \& Paulhus, 2014)도 갖춘 것으로 확 인되었다(Pechorro et al., 2019). SD3는 여러 언 어(독일어, 터키어, 일본어 등)로 번역되어 다 양한 문화권에서 사용되고 있으며(Gamache et al., 2018; Malesza et al., 2019), 어두운 성격 특 성을 측정하기 위해 가장 널리 사용된다. 하 지만 몇 가지 단점 역시 보고되고 있는데 (Rogoza \& Cieciuch, 2018), 먼저 SD3에서는 자 기애의 웅장함의 측면만을 측정하고 낮은 자 존감과 정서적 불안정성이 특징인 취약성 측 면을 측정하지 못한다. 또한, $\mathrm{DD}$ 와 마찬가지 로 사이코패스와 마키아벨리즘의 특성이 중첩 된다는 제한점이 제기되어왔다. 구체적으로, 사이코패스와 마키아벨리즘의 질적 특성 간의 경계가 분명하지 않아 하나의 요인으로 보는 것이 타당하며, 그 결과, 한 요인(자기애)과 또 다른 요인(사이코패스 특성과 마키아벨리즘 특성이 하나로 통합된)으로 구성된 '다크 다이
어드(Dark Dyad)'를 형성한다는 주장(Persson et al., 2019)이 제기되었다. Persson 등(2019)의 연 구에서 탐색적 쌍요인 분석(exploratory bifactor analysis)을 통해 사이코패스 문항은 마키아벨리 즘 요인에 부하되었고, 자기애는 독립적인 요 인임을 확인하였다. 또한, 연구자들은 다섯 개 의 모델을 비교하여 그 중 2 요인 구조가 가장 적절함을 확인하였다. 모델 비교 결과, 마키아 벨리즘 및 사이코패스가 하나의 요인을 구성 하며, 자기애가 두 번째 요인임을 확인하였다. 마키아벨리즘과 사이코패스는 비슷한 성격특 성을 보이며, 다만 그간 이론적으로는 각각의 핵심요인이 자기조절의 문제와 냉담성으로 다소의 차이가 있다는 점이 언급된 바 있다 (Cleckley, 1941). 즉, 마키아벨리즘은 긍정적인 명성을 유지하기 위해 타인과 연합을 하고 미 리 계획을 세우는 특징이 있는 반면, 사이코 패스는 냉담한 속임수를 동반한 충동적인 모 습과 행동의 결과에 대한 무책임한 태도를 보 인다는 것이다(Here \& Neumann, 2008). 그러나 어두운 성격 3 요소의 구조를 경험적으로 확인 한 Rogoza와 Cieciuch(2018)의 연구 결과, 마키 아벨리즘과 사이코패스는 통계적으로 구별되 지 않았으며 자기애와 더불어 어두운 성격 2 요소(dark dyads)를 구성하는 것으로 나타났다. 또한 O'Boyle과 동료들(2015)이 어두운 성격 3 요소와 Big Five 성격 5요인 간의 관계에 대한 메타분석을 한 연구 결과를 보면, 사이코패스 와 마키아벨리즘이 거의 비슷한 패턴으로 성 격 5요인과 관련되었고, 이는 어두운 성격 2 요인 구조를 지지하는 것이다. $\mathrm{SD} 3$ 에 대한 대 부분의 검증연구는 서구권 국가에서 주로 수 행되어 왔기 때문에 Persson과 동료들(2019)은 비서구권 국가에서 $\mathrm{SD} 3$ 의 구성타당도를 살펴 볼 필요성이 있다고 제안하였다. 이러한 제안 
과 더불어 국내에서도 갑질문화가 불거져 어 둠의 성격에 대한 관심이 증가됨에 따라 어두 운 성격 3 요소에 대한 보다 종합적인 연구의 필요성이 제기되고 있다. 그러나 국내에서는 어두운 성격 3 요소인 자기애, 마키아벨리즘, 사이코패스에 대한 각각의 개별 측정도구를 심리측정적 검증 없이 임의로 번안하여 사용 해왔고, 각 어둠의 성격 요소에 대한 문항 수 가 많아 어두운 성격 3 요소를 측정할 때 피수 험자들에게 정확한 의미가 전달되지 않은 채 사용되고 있는 것이 현실이다. 또한 많은 문 항을 한 번에 측정하는 비효율성으로 시간 및 비용 측면에서의 불편함이 제기되어 왔다.

이에 본 연구에서는 어두운 성격 3 요소 측 정도구(SD3)를 한국 성인 남녀를 대상으로 한 국어로 번안·타당화 하고자 하였다. 이 도구 의 심리측정적 속성(신뢰도와 타당도)이 여러 국적의 표본을 대상으로 이미 검증되었지만 (Jones \& Paulhus, 2014), 어두운 성격이라는 특 성 자체가 문화에 따라 가변적일 수 있기 때 문에(Geng et al., 2015) 이 측정도구의 신뢰도 및 타당도가 한국인을 대상으로 했을 때도 동일한 결과가 나오는지를 탐색하는 것이 바 람직하며, 이는 $\mathrm{SD} 3$ 의 외적 타당도를 높이고 문화비교 연구를 수행하는데도 도움이 될 것 이다.

이처럼 $\mathrm{SD} 3$ 의 번안 - 타당화가 필요한 시점 이라는 인식을 바탕으로 본 연구의 목적은 다 음과 같다.

첫째, $\mathrm{SD} 3$ 를 한국어로 번안하고 안정적인 요인 구조의 분석을 위한 표본(500여명)을 사 용하여 한국인을 대상으로 원척도 개발시와 동일한 3가지 요인 구조로 나타나는지 아니면 어둠의 성격 특성이 2 개의 요인으로 구분되는 지 확인하고자 한다.
둘째, 문항반응이론 중 Rasch 모형을 이용하 여 문항 간 의미의 중첩, 문항의 적합성을 검 토하고 재구성하고자 한다. 이때, Rasch 모형을 이용하여 문항의 적합도와 난이도를 평가하면 척도의 완성도가 향상되고, 엄격한 기준으로 문항을 재편(수정, 제거)함으로써 척도의 완성 도를 높일 수 있다(Lee 등, 2007).

셋째, 상기 절차에 따라 확정된 최종 문항 을 토대로 한국판 $\mathrm{SD} 3$ 척도를 구성하고 한국 판 마키아벨리즘 성격척도(MPS), 한국판 자기 애 성격검사(NPI), 한국판 정신병질 자기보고 검사(SRPS), Dirty Dozen 척도들과의 수렴타당 도를 확인한다. 아울러, Ozsoy와 동료들(2017) 이 $\mathrm{SD} 3$ 의 번안 - 타당화에서 준거타당도를 살 펴보지 못했다는 한계점을 보완하기 위하여 어둠의 성격 3 요소와 대안관계문제(비주장성, 과순응성, 자기희생, 통제지배, 자기중심, 과관 여, 냉담, 사회적 억제), 신체화 우울 및 불안 을 측정하는 간이증상체크리스트(BSI-18), 애착 (회피, 불안), 자존감과의 관계를 확인함으로써 준거관련 타당도 추정치를 확인할 것이다. 아 울러 검사-재검사를 통해 신뢰도를 확인할 것 이다.

연구참여자의 피로도를 줄여 신뢰성 높은 응답 자료를 확보할 수 있도록, 적은 수의 문 항으로 구성된 $\mathrm{SD} 3$ 를 한국어로 번안 - 타당화 한 본 연구를 통해 추후 어두운 성격을 가진 직장인들이 조직 문화와 풍토에 어떠한 영향 과 피해를 주는지에 대한 연구, 그리고 어두 운 성격과 관련된 교육훈련의 초점을 확인하 는 데 도움이 될 수 있을 것이다.

\section{연구 1. 탐색적 요인분석}




\section{방 법}

\section{연구대상}

전국의 20 대부터 60 대까지의 성인남녀를 대 상으로 전문설문조사기관에 의뢰하여 수집한 총 250 명의 자료를 분석에 이용하였다. 국내 총 17 개 시/도에서 표집하였으며(예: 서울, 부 산, 대구, 인천, 경기도, 강원도 등), 전문설문 조사기관에서 보유하고 있는 대상자 풀(pool) 중 참여에 동의하고 선택 조건에 부합하는 사 람들의 자료만 수집하였다. 연구 참여자는 남 자 133명(53.2\%), 여자 117 명(46.8\%)이었고, 연 령 분포는 20대 28명(11.2\%), 30대 54명(21.6\%), 40 대 39명(15.6\%), 50대 75명(30.0\%), 60대 이상 54 명 $(21.6 \%)$ 였다. 참여자들의 직업 분포는 직 장인 138 명(55.2\%), 학생 10 명(4.0\%), 자영업 28 명(11.2\%), 주부 37명(14.8\%), 무직 24명(9.6\%), 기타 13 명 $(5.2 \%)$ 으로 나타났다.

\section{측정도구}

\section{단축형 어두운 성격 3요소 설문지(Short \\ Dark Triad; SD3)}

어두운 성격 3요소를 측정하기 위해 Jones와 Paulhus(2014)가 개발한 단축형 어두운 성격 3 요소 측정도구(Short Dark Triad; SD3)를 사용하 였다. 원 저자에게 한국판 $\mathrm{SD} 3$ 의 개발과 타당 화에 대한 동의를 구한 후, 심리학 박사 1 명 과 연구자 3 인, 그리고 이중 언어 사용자(영어, 한국어)인 심리학 박사과정생 1 인, 석사 1 인이 번역-역번역 절차를 수행하였다. 역번역 결과 를 원저자에게 보내 감수를 의뢰했으며, 원저 자 및 공동연구자는 역변역 결과와 원문을 대 조하여 최종 문항을 확정하였다. $\mathrm{SD} 3$ 는 총 27
문항으로 크게 3 개의 하위 요인(자기애, 사이 코패스, 마키아벨리즘)으로 구성되어 있다. 각 하위 요인은 9문항씩 이루어져있으며, 자기애 는 '나는 내가 받아 마땅한 대접받기를 고집 한다.', 사이코패스는 '앙갚음은 빠르고 악랄할 필요가 있다.', 마키아벨리즘은 '내 목적을 달 성하기 위해 교묘하게 조종하는 것을 좋아한 다.와 같은 문항으로 구성되었다. 5점 Likert 형식(1점: 전혀 그렇지 않다 5점: 매우 그렇 다)으로 평정하도록 하였다. Jones와 Paulhus (2014)의 연구에서 보고한 문항 간 내적합치도 (Cronbach's a)는 자기애 .74, 사이코패스 .77, 마키아밸리즘 .71 이었다.

\section{자료분석}

$\mathrm{SD} 3$ 척도의 요인구조를 살펴보기 위하여 탐색적 요인분석을 실시하였다. 먼저 요인 수를 결정하는 것이 가장 중요한 부분이므로 가능한 많은 방법을 사용하는 것이 필요하다 는 Preacher와 MacCallum(2003)의 제안에 따라 PACTOR 10.3(Lorenzo-Seva \& Ferrando, 2015)를 이용해서 평행분석(Parallel Analysis)과 Velicer의 $\mathrm{MAP}$ (minimum average partial) 분석을 통해 요인 수를 결정하였다. 이를 통해 확인된 요인 수 를 기준으로 공통요인분석을 실시하여 요인구 조와 문항을 구체화하고 의미를 살펴보았다. 공통요인분석으로는 주축 요인(Principal Axis Factoring)과 사각회전인 프로맥스회전(Promax rotation)을 이용하였다. 탐색적 요인분석을 실 시한 후 확인된 하위 요인들과 전체 척도의 내적 합치도를 산출하고, 요인들 간 상관분석 을 실시하였다. 모든 통계적 분석에는 SPSS 18.0 을 사용하였다. 


\section{결 과}

한국인을 대상으로 $\mathrm{SD} 3$ 의 요인구조를 탐 색하기 위해 27 개 문항에 대한 탐색적 요인 분석을 실시하고 표본적합도를 살펴본 결과, $\mathrm{KMO}$ (Kaiser-Meyer-Olkin)값이 .85 , Bartlett의 구 형성 검증 결과 $\left(\chi^{2}=2301.73, p<.001\right)$ 가 유 의한 것으로 나타나 수집된 자료가 요인분석 에 적합한 것을 확인하였다(Tabachnick \& Fidell, 1996). 요인 수를 결정하기 위하여 평행분석과 Velicer의 MAP 분석을 실시한 결과, 2 개 요인 이 적절한 것으로 나타났다. 따라서 2요인을 기준으로 3-5개 요인에 대한 탐색적 요인분 석을 실시하였고, 스크리 도표와 해석 가능성 을 고려하여 최종적으로 2요인 모형을 선택 하였다.

이후 요인 수를 2개로 고정하여 탐색적 요 인분석을 실시하였으며, 분석에는 주축요인 추출과 사각회전인 프로맥스회전(PROMAX rotation)이 이용되었다. 요인분석 결과를 기반 으로 이후 요인 수를 2개로 고정하여 탐색적 요인분석을 실시하였으며, 분석에는 주축요인 추출과 사각회전인 프로맥스회전(PROMAX rotation)이 이용되었다. 요인분석 결과를 기반 으로, 1) 각 문항이 해당하는 요인의 부하량이 .30 이하(Costello \& Osborne, 2005)이거나, 2) 다른 요인과의 교차부하량 차이가 .20 이하 (Howard, 2016)인 문항을 최종 문항에서 제외 하였다. 그 결과, 요인부하량이 .30 이하인 1 번 문항(나의 비밀을 타인에게 말하는 것은 현명하지 않다고 생각한다), 15 번 문항(나는 누군가가 나를 칭찬하면 당황하는 편이다), 24 번 문항(나를 함부로 대한 사람들은 항상 그 일을 후회한다), 25 번 문항(나는 법을 한 번 도 어긴 적이 없다)과 교차요인부하량이 .15
이하인 4번 문항(미래에 누가 나에게 도움이 되는 사람인지 알 수 없으니 사람들과 직접 적인 마찰은 피한다), 11 번 문항(나는 많은 사 람들의 관심의 대상이 되는 것을 몹시 싫어 한다), 19 번 문항(나는 권력을 가진 자들에게 복수하는 것을 좋아한다), 20 번 문항(나는 위 험한 상황은 피한다), 26번 문항(나는 모르는 사람과 성관계 맺는 것을 즐긴다), 총 9 개 문 항을 제외한, 18 문항의 2 개 요인 구조를 확 인하였다.

탐색적 요인분석을 통해 나타난 요인들을 살펴보면, 요인 1 은 총 12 문항으로 고유치 는 6.05 , 설명변량은 $33.63 \%$ 였으며, Jones와 Paulhus(2014)의 원척도에서 사이코패스 요인과 마키아벨리즘 요인에 해당되는 문항들이 포함 되어 마키아벨리즘-사이코패스(이하 Ma-Psy)로 명명하였다. 다음으로 요인 2는 총 6문항으로 아이겐 값은 2.29, 설명변량은 12.72 였으며, 모 두 원척도의 자기애 요인에 해당하는 문항들 이므로 원척도의 요인 명을 그대로 따라 자기 애라고 명명하였다. 그 결과를 표 1 에 제시하 였다.

\section{내적 합치도와 요인들 간 상관}

우선 18 문항으로 수정된 $\mathrm{SD} 3$ 척도의 내적 합치도를 살펴본 결과, 전체 $\mathrm{SD} 3$ 은 .86 이었으 며, 하위 요인인 사이코패스와 자기애는 각각 $.84, .76$ 로 양호하였다. 전체 $\mathrm{SD} 3$ 점수와 하위 요인들 간 상관관계를 살펴본 결과, 전체 점 수 및 하위 요인들 간 상관은 모두 정적으로 유의하였다 $(r s=.42 \sim .94, p<.001)$. 그 결 과는 표 2와 같다. 
Table 1. Results of exploratory factor analysis of the final 18 items of the Short Dark Triad $(N=250)$

\begin{tabular}{|c|c|c|c|}
\hline & items & Factor 1 & Factor 2 \\
\hline 21. & $\begin{array}{l}\text { Payback needs to be quick and nasty. } \\
\text { (나는 보복은 빠르게 이루어져야 하고 심술굿을 필요가 있다고 생각한다.) }\end{array}$ & .69 & .03 \\
\hline 7. & $\begin{array}{l}\text { There are things you should hide from other people to preserve your reputation. } \\
\text { (나는 좋은 평판을 유지하기 위해 다른 사람들로부터 숨겨야 할 것들이 있다.) }\end{array}$ & .68 & -.04 \\
\hline 6. & $\begin{array}{l}\text { You should wait for the right time to get back at people. } \\
\text { (나는 다른 사람들에게 복수할 적절한 시기를 모색하기 위해 기다리는 편이다.) }\end{array}$ & .66 & .12 \\
\hline 23. & $\begin{array}{l}\text { It's true that I can be mean to others. } \\
\text { (나는 다른 사람에게 못되게 굴 수 있다.) }\end{array}$ & .65 & -.20 \\
\hline 2. & $\begin{array}{l}\text { I like to use clever manipulation to get my way. } \\
\text { (나의 목적을 달성하기 위해 타인을 교묘하게 조종하는 것을 좋아한다.) }\end{array}$ & .65 & .10 \\
\hline 8. & $\begin{array}{l}\text { Make sure your plans benefit yourself, not others. } \\
\text { (나의 계획들은 다른 사람들을 아닌, 나에게 득이 되는 것이어야 한다.) }\end{array}$ & .64 & -.08 \\
\hline 3. & $\begin{array}{l}\text { Whatever it takes, you must get the important people on your side. } \\
\text { (무슨 수를 써서라도 중요한 사람들은 내 편에 두어야 한다.) }\end{array}$ & .61 & .09 \\
\hline 5. & $\begin{array}{l}\text { It's wise to keep track of information that you can use against people later. } \\
\text { (나중에 사람들에게 맞서기 위해 내가 활용할 수 있는 정보를 계속 저장해 놓는 것은 현명한 일이라고 생각한다.) }\end{array}$ & .60 & -.16 \\
\hline 27. & $\begin{array}{l}\text { I'll say anything to get what I want. } \\
\text { (원하는 것을 얻기 위해서라면 나는 그 어떤 말도 할 수 있다.) }\end{array}$ & .59 & .23 \\
\hline 22. & $\begin{array}{l}\text { People often say I'm out of control. } \\
\text { (사람들은 종종 내가 통제가 불가능하다고 한다.) }\end{array}$ & .54 & .15 \\
\hline 9. & $\begin{array}{l}\text { Most people can be manipulated. } \\
\text { (대부분의 사람들은 조종 당할 수 있다고 생각한다.) }\end{array}$ & .49 & -.10 \\
\hline 18. & $\begin{array}{l}\text { I insist on getting the respect I deserve. } \\
\text { (나는 나에게 합당한 대접을 받을 것을 고집하는 편이다.) }\end{array}$ & .34 & .13 \\
\hline 16. & $\begin{array}{l}\text { I have been compared to famous people. } \\
\text { (나는 유명 인사들과 비교되곤 했다.) }\end{array}$ & -.03 & .80 \\
\hline 10. & $\begin{array}{l}\text { People see me as a natural leader. } \\
\text { (사람들은 나를 타고난 리더라고 생각한다.) }\end{array}$ & -.24 & .79 \\
\hline 12. & $\begin{array}{l}\text { Many group activities tend to be dull without me. } \\
\text { (내가 없다면 많은 그룹 활동들이 지루해지는 경향이 있다.) }\end{array}$ & -.06 & .67 \\
\hline 13. & $\begin{array}{l}\text { I know that I am special because everyone keeps telling me so. } \\
\text { (모든 사람들이 지속적으로 말해주기 때문에 나는 내가 특별한 사람이라고 생각한다.) }\end{array}$ & .02 & .66 \\
\hline 14. & $\begin{array}{l}\text { I like to get acquainted with important people. } \\
\text { (나는 주요 인사들과 알게 되는 것을 좋아한다.) }\end{array}$ & .14 & .46 \\
\hline 17. & $\begin{array}{l}\text { I am an average person. (R) } \\
\text { 나는 평범한 사람이다. (역) }\end{array}$ & .12 & .46 \\
\hline & Eigen Value (고유값) & 6.05 & 2.29 \\
\hline & Varience Explained (설명변량) & 33.63 & 12.72 \\
\hline & Total Varience Explained (누적설명변량) & 33.63 & 46.35 \\
\hline
\end{tabular}

Note. The item numbers correspond to the original version of the short dark triad Scales(Jones \& Paulhus, 2014)

Note. Pattern matrix from factor analysis with factor loadings 
Table 2. Intercorrelations of the Short Dark Triad

\begin{tabular}{cccc}
\hline & SD3_Total & $\begin{array}{c}\text { Machiavellianism-Psychopathy } \\
\text { (Ma-Psy) }\end{array}$ & Narcissism \\
\hline SD3_Total & - & & \\
Ma-Psy & $.94 * * *$ & - & - \\
Narcissism & $.71 * * *$ & $.42 * * *$ & - \\
\hline
\end{tabular}

**** $p<.001$.

\section{논 의}

연구 1 에서는 국내 성인들을 대상으로 Jones 와 Paulhus(2014)가 개발한 SD3 척도의 27개 문 항에 대한 요인구조를 살펴보기 위하여 탐색 적 요인분석을 실시하였다. 그 결과, Jones와 Paulhus(2014)의 척도 개발 당시의 3요인 구조 와는 달리 한국에서는 2 요인 구조로 확인되었 다. 이는 $\mathrm{SD} 3$ 에서 마키아벨리즘과 사이코패스 를 하나의 요인으로 봐야한다는 선행연구들 (Persson et al., 2019; Vize et al., 2018)과 일치하 는 결과이다. 본 연구의 $\mathrm{SD} 2$ 는 자기애, 마키아 벨리즘-사이코패스 2요인구조로 나타났다. 자 기애 요인이 마키아벨리즘-사이코패스 요인에 비해 대인관계적인 특성(예. 웅대한 자기상, 인상관리)을 반영한다(Kim, 2009)는 점에서 두 개념이 구별될 가능성이 있다.

특히, 마키아벨리즘과 사이코패스가 하나의 요인(마키아벨리즘-사이코패스)으로 나타난 이 유로 $\mathrm{SD} 3$ 을 구성하는 문항의 질적 특성에서 찾아볼 수 있다. 구체적으로, 선행연구에서 충 동성이 마키아벨리즘과 사이코패스를 구별하 는 주요한 특성 중 하나로 밝혀진 바 있다 (Poythress \& Hall, 2011). 마키아벨리즘의 핵심 요소는 전략적 조작, 전략적 냉담함, 본인의 이득을 위한 계산적 지향성(Jones \& Paulhus,
2014)인 반면, 사이코패스의 두 가지 핵심 요 소는 냉담함과 충동성이다(Lykken, 1995). SD3 는 마키아벨리즘과 사이코패스를 구별하는 충 동성(Yildirim \& Derksen, 2015)을 측정하는 문 항이 포함되어 있지 않기 때문에 사이코패스 와 마키아벨리즘을 구별하기 어려운 것으로 보이며, 그 결과 2요인 구조가 한국인의 어둠 의 성격의 특징을 보다 잘 나타낼 가능성이 있다.

\section{연구 2. 확인적 요인분석 및 타당도 분석}

\section{방 법}

연구대상

연구 1 과 동일하게, 전국의 20 대부터 60 대 까지의 성인남녀를 대상으로 전문여론조사기 관에 의뢰하여 수집한 총 250 명의 자료를 분 석에 이용하였다. 국내 총 17 개 시/도에서 표 집하였으며(예. 서울, 부산, 대구, 인천, 경기도, 강원도 등), 전문여론조사기관에서 보유하고 있는 대상자 풀(pool) 중 참여에 동의하고 선택 조건에 부합하는 사람들의 자료만 수집하였다. 연구 참여자는 남자 108 명(43.2\%), 여자 142 명 
(56.8\%)이었고, 연령 분포는 20대 68명(27.2\%), 30 대 46명(18.4\%), 40대 61명(24.4\%), 50대 28명 (11.2\%), 60대 이상 47 명(18.8\%)였다. 참여자들 의 직업 분포는 직장인 191 명(76.4\%), 학생 9 명(3.6\%), 자영업 9명(3.6\%), 주부 17명(6.8\%), 무직 19명(7.6\%), 기타 5명(2.0\%)으로 나타났다.

\section{측정도구}

\section{단축형 어두운 성격 3요소 설문지(Short}

\section{Dark Triad; SD3)}

어두운 성격 3요소를 측정하기 위하여 캐나 다에서 개발-타당화된 27문항 $\mathrm{SD} 3$ 대신, 연 구 2 에서는 연구 1 의 결과를 반영한 2 요인 구 조인 SD2 18 문항을 사용하였다. 각 하위 요인 의 전체 문항 간 내적합치도(Cronbach's a)는 .85 였으며, 하위 요인은 자기애 .75, 마키아벨 리즘-사이코패스(Ma-Psy) .84이었다.

\section{한국판 마키아벨리즘 성격척도(Korean}

Version of the Machiavellianism Personality Scale;

\section{K-MPS)}

마키아벨리즘 성격 특성을 측정하기 위하여 Dahling 등(2009)이 개발하고 Kim 등(2011)이 번안 및 타당화한 한국판 마키아벨리즘 성격 척도(Korean Version of the Machiavellianism Personality Scale; K-MPS)를 사용하였다. K-MPS 는 총 15 문항, 4 개의 하위 요인(타인에 대한 불신, 지위에 대한 욕구, 통제에 대한 욕구, 비도덕적 조종)으로 구성되어있다. 점수가 높 을수록 마키아벨리즘 성향이 높은 것을 의미 하며, 4점 Likert 형식(1점: 매우 그렇지 않 다 4점: 매우 그렇다)으로 평정한다. $\mathrm{Kim}$ 등 (2011)이 보고한 전체 문항 간 내적합치도 (Cronbach's a)는 .80이었으며, 본 연구에서의
내적합치도는 전체 .89 , 각 하위 요인은 타인 에 대한 불신 .81 , 부도덕적 조종 .84 , 지위에 대한 옥구 .77 , 통제에 대한 옥구 .77 로 나타 났다.

\section{자기애성 성격검사(Narcissistic Personality}

\section{Inventory; NPI)}

자기애 성격 특성을 측정하기 위하여 Raskin과 Hall(1979)이 개발하고 Han(1999)이 번 안한 자기애성 성격검사(Narcissistic Personality Inventory; NPI)를 사용하였다. NPI는 총 40 문 항이며, '나는 사람들에게 영향력을 행사하는 타고난 능력이 있다.' 또는 '나는 사람들에게 영향을 주지 못한다.와 같은 두 개의 문장을 제시하고 하나의 문장을 선택하는 형식의 질 문지를 사용하였다. 자기애적인 내용의 문항 을 선택하면 1점, 그렇지 않은 문항을 선택하 면 0점으로(점수범위 0점 40점), 점수가 높을 수록 자기애적 성향이 높은 것을 의미한다. $\mathrm{Han}(1999)$ 의 연구에서 보고한 전체 문항 간 내 적합치도(Cronbach's a)는 .80이었으며, 본 연구 에서의 내적합치도는 .86로 나타났다.

\section{정신병질 자기보고검사(the self-report}

\section{Psychopathy Scale: SRPS)}

사이코패스 성격특성을 측정하기 위하여 Levenson 등(1995)이 개발하고 Lee와 Kim(2011) 이 번안 및 타당화한 정신병질 자기보고검사 (Self-report Psychopathy Scale: SRPS) 를 사용하였 다. SRPS는 총 26문항으로, '성공이란 어차피 생존경쟁의 결과이다. 나는 패자에게 신경 쓰 지 않는다.와 같은 문장으로 구성된다. 점수가 높을수록 사이코패스 성격 성향이 높은 것을 의미하며, 4점 Likert 형식(1점: 정말 아니다 4 점: 정말 그렇다)으로 평정한다. Yang 등(2011) 
이 보고한 문항 간 내적합치도(Cronbach's a) 범위는 .72 이었으며, 본 연구에서의 내적합치 도는 전체 .74 이었다.

\section{Dirty Dozen 척도}

$\mathrm{SD} 3$ 의 수렴타당도를 알아보기 위해, 부정 적인 성격특성을 측정하는 Dirty Dozen 척도 를 사용하였다. Dirty Dozen 척도는 Jonason과 Webster(2010)가 개발하고, Myung(2016)이 번안 한 도구로, 총 12 문항으로 구성된다. 하위 요 인은 각각 마키아밸리즘, 사이코패스, 자기애 이며, '나는 내 길을 가기 위해 다른 사람을 능수능란하게 다룬다.'와 같은 문항으로 이루 어져있다. 9점 Likert 형식(1점: 전혀 그렇지 않 다 9점: 매우 그렇다)으로 평정한다. Myung (2016)이 보고한 문항 간 내적합치도(Cronbach's a)는 .90 이었으며, 본 연구에서의 전체 내적합 치도는 .86 , 마키아밸리즘 .83 , 사이코패스 .64 , 자기애 .89로 나타났다.

\section{한국형 대인관계문제검사 원형척도 단축형} (Short form of the Korea Inventory of Interpersonal Problems-Circumplex Scales; KIIP-CS)

대인관계문제를 평가하기 위하여 Horowitz 등(1988)이 개발하고 Hong 등(2002)이 표준화 한 한국형 대인관계문제검사(KIIP)를 Hong 등 (2002)이 단축형으로 구성한 한국형 대인관계 문제검사 원형척도 단축형(KIIP-SC)을 사용하 였다. '내가 원하는 것을 말하기가 어렵다'와 같이 대인관계에서의 어려움에 대한 문항으로 구성되어, 점수가 높을수록 대인관계 어려움 이 큰 것을 의미한다. 5점 Likert 형식(1점: 전 혀 그렇지 않다 5점: 매우 그렇다)으로 평정 한다. 전체 40 문항, 8 개의 하위 요인(냉담, 사 회적 억제, 자기중심성, 비주장성, 자기희생,
과순응성, 통제지배, 과관여)으로 구성되어 있 다. Hong 등(2002)의 연구에서 보고한 하위 요인 문항의 내적합치도(Cronbach's a) 범위는 .61 .89이었으며, 본 연구에서는 각각 냉담 .88 , 사회적 억제 .81 , 자기중심성 .86 , 비주장 성 .91 , 자기희생 .71 , 과순응성 .83 , 통제지배 .85 , 과관여 .79 이었다.

\section{간이정신진단검사 단축형-18(Brief Symptoms} Inventory-18; BSI-18)

심리적 불편감을 측정하기 위하여 Derogatis (2001)가 개발하고, Park 등(2012)이 한국어로 번안 및 타당화 한 BSI-18를 사용하였다. $\mathrm{BSI}-18$ 는 18 문항으로 3 개의 하위 요인(신체화, 우울, 불안)으로 구성되어 있다. Likert 형식(0 점: 전혀 그렇지 않다 4점: 매우 그렇다)으로 평정하며, 점수가 높을수록 심리적 불편감이 크다는 것을 의미한다. Park 등(2012)의 연구에 서 내적합치도(Cronbach's a)는 각각 신체화 .73 , 우울 .80 , 불안 .81 였으며, 본 연구에서는 신체화 .89 , 우울 .88 , 불안 .90으로 나타났다.

\section{친밀관계경험 질문지(Experience in Close}

\section{Relationships Questionnaire; ECR-R)}

성인애착을 측정하기 위해 Brennan 등(1998) 이 개발하고, 이후 Fraley 등(2000)이 개정하고, $\operatorname{Kim}(2004)$ 이 번안 및 타당화한 친밀관계경험 질문지(ECR-R)를 사용하였다. 7점 Likert 형식(1 점: 전혀 그렇지 않다 7점: 매우 그렇다)으로 평정하며, 점수가 높을수록 애착불안 및 애착 회피 수준이 높고 불안정함을 의미한다. Cho 와 Seo(2010)의 연구에서 보고한 ECR-R의 내적 합치도(Cronbach's a)는 애착불안 .89, 애착회피 는 .90 이었으며, 본 연구에서의 내적합치도 (Cronbach's a)는 불안애착이 .93 , 회피애착이 
.89 로 나타났다.

\section{로젠버그 자존감 척도(Rosenberg Self-Esteem}

Scale; RSS)

자존감을 평가하기 위하여 Rosenberg(1965)가 개발하고 Lee와 Won(1995)이 번안한 로젠버그 자존감 척도(Rosenberg Self-Esteem Scale; RSS)를 사용하였다. RSS는 Likert식 5점 척도(1점: 전혀 그렇지 않다 매우 그렇다)이며, 긍정문항 5 문 항과 부정문항 5 문항 총 10 문항으로 구성된다. 점수가 높을수록 자존감 수준이 높음을 의미 한다. Lee와 Won(1995)의 연구에서 보고한 문 항 간 내적합치도(Cronbach's a)는 .89였으며, 본 연구에서의 내적합치도는 .90 이었다.

\section{자료분석}

연구 1 의 탐색적 요인분석을 통해 2 요인으 로 구성된 SD2 척도의 요인 구조가 다른 표본 에서도 타당한지를 살펴보기 위하여 새로운 성인 표본을 대상으로 확인적 요인분석을 실 시하였다. 확인적 요인분석은 Mplus 7.0을 이 용하였고, 모수 추정 방식은 최대우도 추정법 (Maximum Likelihood)을 사용하였다. 모형 적합 도를 판단하는 지수로는 CFI, TLI, RMSEA를 이용하였고, Hong(2000) 및 $\mathrm{Hu}$ 와 Bentler(1999) 의 기준에 따라 $\mathrm{CFI}$ 와 TLI는 .90 이상, RMSEA 는 .08 이하이면 좋은 적합도, .10 이하이면 보통 적합도로 평가하였다. 다음으로 문항의 타당성을 평가하기 위하여 WINSTEPS(Linacre, 2005)을 이용하였다. Rasch 모형 중 다점척도 모형(Polytomous Model)인 Andrich(1978)의 평정 척도모형(Rating Scale Model: RSM)을 적용하여 분석하였고, 응답범주에 대한 범주확률곡선, 내적합도지수와 외적합도지수, 피험자 $\times$ 문항
분포도를 통해 문항의 적절성을 확인하였다. 마지막으로 SPSS 21.0 을 이용하여 SD2 척도의 수렴 타당도와 준거 타당도를 살펴보기 위한 상관분석을 실시하였고, 내적 합치도와 검사재검사 신뢰도(1개월 간격)를 검증하였다.

\section{결 과}

\section{확인적 요인분석}

탐색적 요인분석을 통해 수정된 18 문항의 $\mathrm{SD} 2$ 척도의 구성타당도 검증을 위해 전국 성 인 250명을 대상으로 Mplus 7.0을 이용한 확인 적 요인분석을 실시하였다. 분석 결과, 모형 적합도는 좋은 것으로 나타났다 $\left[\chi^{2}(d f=153)\right.$ $=2828.49$, CFI $=.918$, TLI $=.906$, RMSEA $=$ $.081(90 \% \mathrm{CI}=.071-091)]$. 다만, 표 3에서 볼 수 있듯이 자기애 요인에 대한 17번 문항(나 는 평범한 사람이다)의 요인부하량이 .28로 .30 보다 낮아서 추가로 제거하게 되었다. 이를 제외한 나머지 17 개 문항의 표준화 요인계수 는 $.38 \sim .82$ 로 나타났다. 따라서 최종적으로 2요인 17문항으로 구성된 SD2 척도를 확정하 였다. 확정된 $\mathrm{SD} 2$ 척도의 요인별 남녀 평균과 표준편차를 살펴보면 남성의 경우 마키아벨리 즘-사이코패스(Ma-Psy) 요인의 평균은 34.23, 표 준편차는 7.40 , 자기애 요인의 평균은 13.61 , 표준편차는 3.45 이었다. 반면 여성의 경우 마 키아벨리즘-사이코패스(Ma-Psy) 요인의 평균은 32.03 , 표준편차는 6.84 , 자기애 요인의 평균은 12.87 , 표준편차는 3.26 이었다. 
박종철 등 / 한국판 어두운 성격 3 요소 단축형의 요인구조와 타당화 지표

Table 3. Coefficients of 2-factor structure of the SD2

\begin{tabular}{|c|c|c|c|c|c|}
\hline & & $B$ & $S E$ & $\beta$ & $t$ \\
\hline \multirow{12}{*}{$\begin{array}{c}\text { Machiavellianism } \\
\text {-Psychopathy } \\
\text { (Ma-Psy) }\end{array}$} & item 2 & 1.00 & .00 & .74 & \\
\hline & item 3 & .97 & .07 & .71 & $14.82^{* * *}$ \\
\hline & item 5 & .74 & .08 & .55 & $9.63^{* * *}$ \\
\hline & item 6 & 1.05 & .06 & .78 & $17.26^{* * *}$ \\
\hline & item 7 & .68 & .07 & .50 & $10.39^{* * *}$ \\
\hline & item 8 & .51 & .07 & .38 & $7.06^{* * *}$ \\
\hline & item 9 & .52 & .08 & .38 & $6.78^{* * *}$ \\
\hline & item 18 & .55 & .07 & .41 & $7.55^{* * *}$ \\
\hline & item 21 & .99 & .06 & .73 & $15.96^{* * *}$ \\
\hline & item 22 & .87 & .07 & .64 & $12.81^{* * *}$ \\
\hline & item 23 & .79 & .07 & .58 & $11.82^{* * * *}$ \\
\hline & item 27 & 1.00 & .06 & .73 & $16.08^{* * *}$ \\
\hline \multirow{6}{*}{ Narcissism } & item 10 & 1.00 & .00 & .55 & \\
\hline & item 12 & 1.28 & .16 & .71 & $7.88^{* * *}$ \\
\hline & item 13 & 1.37 & .17 & .76 & $8.15^{* * *}$ \\
\hline & item 14 & .97 & .15 & .54 & $6.63^{* * *}$ \\
\hline & item 16 & 1.48 & .18 & .82 & $8.31^{* * *}$ \\
\hline & item 17 & .51 & .12 & .28 & $4.23^{* * * *}$ \\
\hline
\end{tabular}

${ }^{* * *} p<.001$.

\section{문항 적절성}

$\mathrm{SD} 2$ 척도의 내적 구조의 타당성을 확인하 였기 때문에 Rasch 모형을 이용하여 개별 문항 들의 타당성을 살펴보았다. 응답범주의 적절 성 검증 이후 문항 적합도를 바탕으로 부적합 한 문항을 확인하였고, 마지막으로 응답자 $\times$ 문항 분포도(person-item-map)를 바탕으로 응답 자들의 속성들과 문항의 동의하기 어려운 정 도를 비교하였다.

\section{응답범주에 대한 범주확률곡선}

$\mathrm{SD} 2$ 척도의 문항 응답범주(Likert 5점 척도) 가 적절한지를 확인하기 위하여 범주 확률곡 선(category probability curve)을 살펴보았다. 그 림 1 에서 $\mathrm{X}$ 축은 하위 요인들에 대한 개인의 속성과 문항 난이도 사이의 로짓 차이(person measure relative to item difficulty), $\mathrm{Y}$ 축은 특정 범주가 선택될 확률(category probability)이며, 각 곡선은 왼쪽에서부터 1점(전혀 그렇지 않다)에 서 5점(매우 그렇다)까지의 응답범주이다. 2개 
Machiavellianism-Psychopathy

(Ma-Psy)

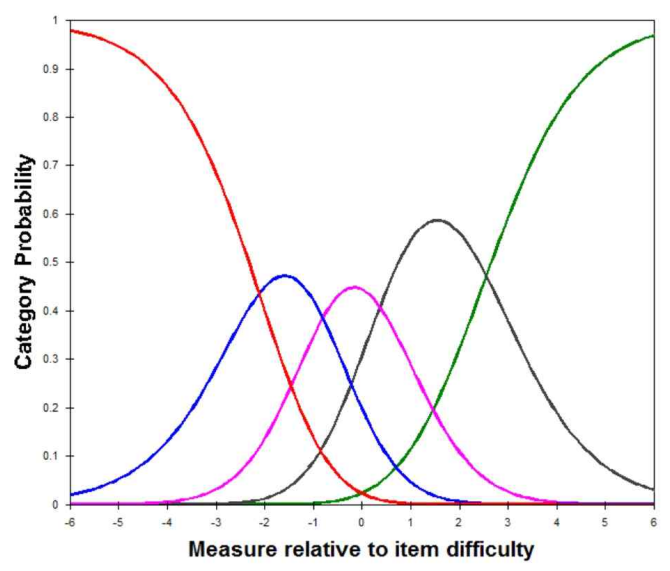

Narcissism

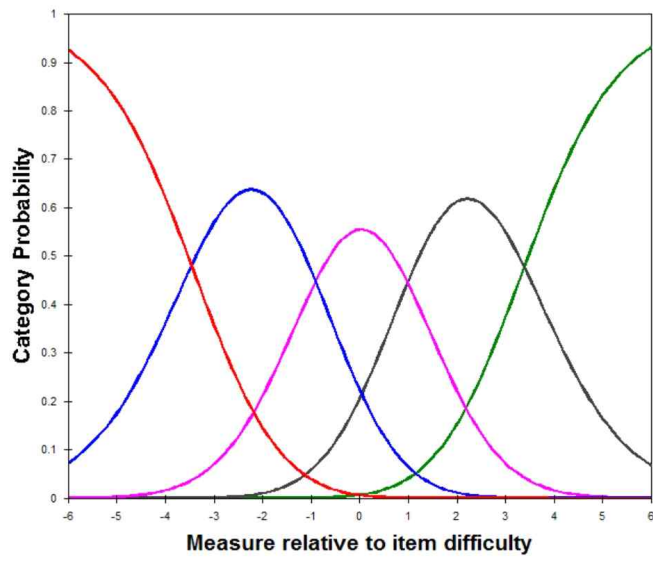

Figure 1. Category probability curves (범주확률곡선)

하위 요인들 모두 개별 곡선이 다른 곡선에 포함되지 않고 $\mathrm{X}$ 축의 특정 영역에서 적어도 한 번은 가장 높은 확률을 보이기 때문에 5점 의 응답범주가 적절하였음을 확인할 수 있다.

\section{문항 적합도}

각 하위 요인들에 속하는 문항들의 타당성 을 살펴보았고, 그 결과를 표 4에 제시하였다. 이를 위해 응답자들의 응답이 Rasch 모형을 통 해 기대되는 확률값과 응답자의 실제 반응값 의 비교를 통해 검증하는 타당도 지수인 내적 합도(Infit Mean Square: Infit MNSQ)와 외적합도 (Outfit Mean Square: Outfit MNSQ)를 확인하였 다. 외적합도의 경우 응답자의 속성 정도에 비해 동의하기 쉬운 문항에 대해 동의하지 않 았거나 동의하기 어려운 문항에 대해 동의한 경우처럼 이상 문항 반응 형태에 민감한 지수 이며, 내적합도는 극소수의 이상 문항 반응에 영향을 받는 외적합도를 보완하기 위해 피험
자의 속성 정도에서 많이 벗어나지 않은 문항 의 이상 문항 반응에 가중치를 둔 적합도 지 수이다(Wright \& Masters, 1982). 양호한 문항에 대한 두 적합도의 기대값은 1 이며, 두 적합도 지수 모두 .60 이상 1.40 이하의 범위일 경우 해당 문항의 적합도가 좋은 것으로 판단하였 다(Linacre, 2011).

분석결과, 모든 문항들의 내적합도와 외적 합도 지수가 .60 이상, 1.40 이하로 나타나 문 항 적합도가 양호한 것으로 나타났다. 그 결 과는 표 4 와 같다.

\section{응답자 $\times$ 문항 분포도}

응답자들의 속성 정도와 문항에 동의하기 어려운 정도(difficulty level)를 로짓(logit)으로 동 일하게 변환시켜 문항들의 동의하는 정도가 응답자 집단에 적절했는지를 직접 비교, 평가 할 수 있는 응답자 $\times$ 문항 분포도를 그림 2 에 제시하였다(Hong et al., 2005). 그림의 가운 
박종철 등 / 한국판 어두운 성격 3요소 단축형의 요인구조와 타당화 지표

Table 4. Rating scale model fit statistics of the optimal categorization

\begin{tabular}{|c|c|c|c|c|}
\hline Factor & Items & $\begin{array}{l}\text { Item difficulty } \\
\text { (동의하기 } \\
\text { 어려운 정도) }\end{array}$ & $\begin{array}{c}\text { Infit } \\
\text { 내적합도 }\end{array}$ & $\begin{array}{c}\text { Outfit } \\
\text { 외적합도 }\end{array}$ \\
\hline \multirow{12}{*}{$\begin{array}{c}\text { Machiavellianism } \\
\text {-Psychopathy } \\
\text { (Ma-Psy) }\end{array}$} & item 2 & 1.01 & .86 & .87 \\
\hline & item 3 & -.13 & .84 & .86 \\
\hline & item 5 & -1.16 & 1.09 & 1.08 \\
\hline & item 6 & .41 & .82 & .81 \\
\hline & item 7 & -.49 & 1.13 & 1.11 \\
\hline & item 8 & -.80 & 1.05 & 1.08 \\
\hline & item 9 & -.40 & 1.25 & 1.31 \\
\hline & item 18 & -.65 & .98 & 1.03 \\
\hline & item 21 & .55 & .76 & .77 \\
\hline & item 22 & .87 & 1.10 & 1.11 \\
\hline & item 23 & -.02 & 1.14 & 1.12 \\
\hline & item 27 & .83 & .90 & .95 \\
\hline \multirow{5}{*}{ Narcissism } & item 10 & .23 & 1.09 & 1.14 \\
\hline & item 12 & .15 & .89 & .88 \\
\hline & item 13 & -.16 & .82 & .82 \\
\hline & item 14 & -.94 & 1.13 & 1.16 \\
\hline & item 16 & .71 & 1.07 & 1.03 \\
\hline
\end{tabular}

데 세로선을 기준으로 왼편에는 개인의 속성 정도 분포가, 오른편에는 문항에 동의하기 어 려운 정도 분포가 나타나 있으며, 두 분포의 범위가 어느 정도 일치할 때, 개인의 속성 정 도의 모든 범위를 측정할 수 있도록 문항들의 동의하기 어려운 정도가 분포되었다고 볼 수 있을 것이다.

확인 결과를 그림 2에 제시하였고 마키아벨 리즘-사이코패스(Ma-Psy) 요인과 자기애 요인 모두 각 문항의 동의하기 어려운 정도와 응답 자의 속성 점수 분포 범위가 대체로 일치하여
문항들이 개인의 속성 정도를 측정할 수 있는 정도로 분포되었다고 할 수 있다. 다만, 마키 아벨리즘-사이코패스(Ma-Psy) 요인에 비해 자 기애 요인의 문항 수가 상대적으로 적어서 자 기애 속성이 낮은 응답자들을 위한 문항들이 부족한 것을 확인할 수 있었다.

\section{내적 합치도}

$\mathrm{SD} 2$ 의 내적 합치도를 살펴본 결과, 전체 $\mathrm{SD} 2$ 는 .86이었으며, 하위 요인인 마키아벨리즘 
한국심리학회지: 산업 및 조직

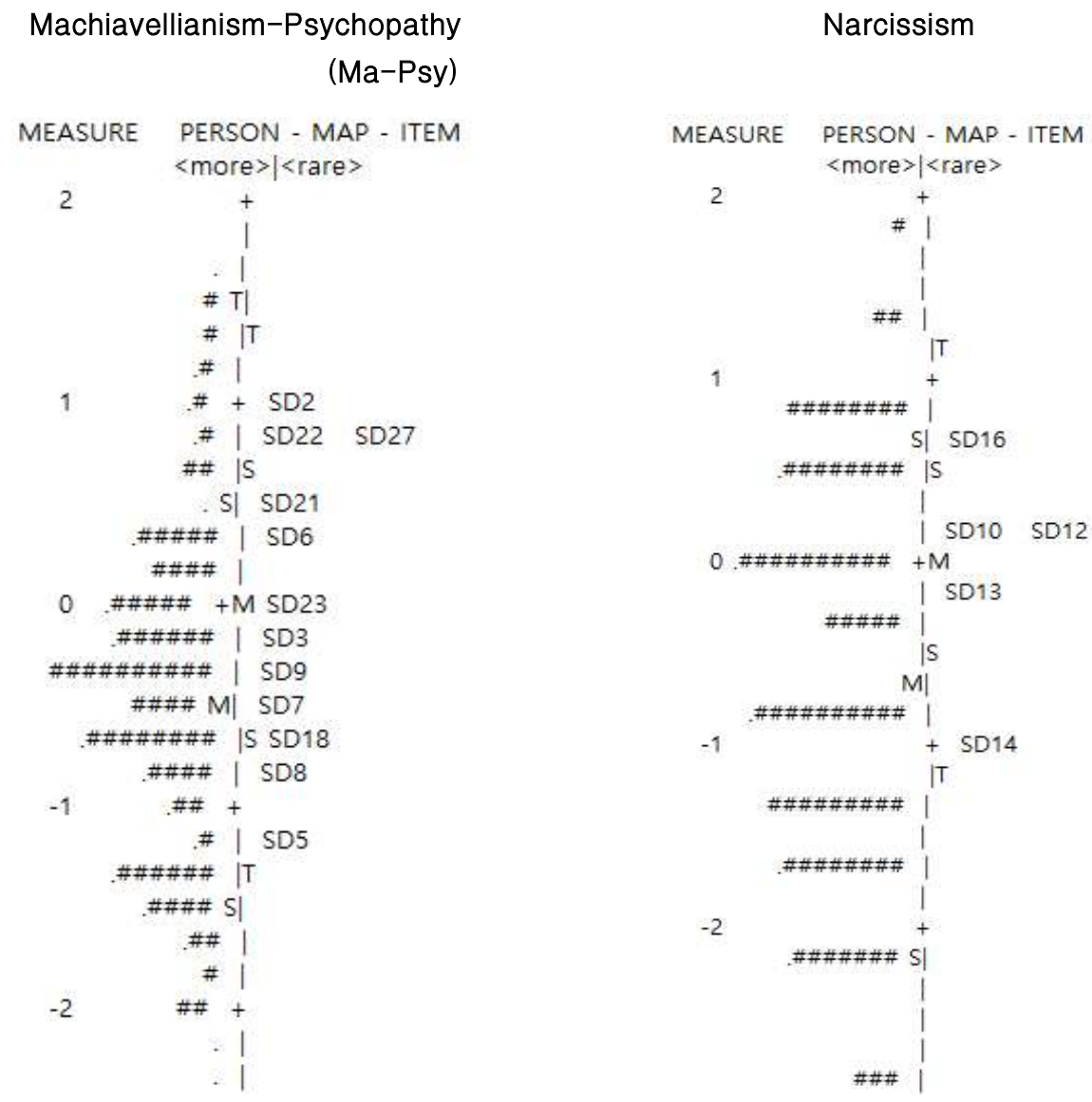

Figure 2. Distribution of persons and items

-사이코패스(Ma-Psy)와 자기애는 각각 $.84, .76$ 로 양호하였다.

\section{수렴 타당도}

$\mathrm{SD} 2$ 척도의 수렴 타당도를 살펴보기 위하 여 기존의 어둠의 성격과 관련된 변인들과의 상관분석을 실시하였고, 그 결과를 표 5에 제 시하였다. 분석 결과, 전체 $\mathrm{SD} 2$ 및 하위 요인 들 모두 관련 변인들과의 정적 상관이 통계적 으로 유의하였다. 특히, 마키아벨리즘-사이코 패스(Ma-Psy)는 MPS_마키아벨리즘 $(r=.75, p$
$<.001)$, SRPS_사이코패스 $(r=.61, p<.001)$, Dirty Dozen_마키아벨리즘 $(r=.61, p<.001)$, Dirty Dozen_사이코패스 $(r=.50, p<.001)$ 와의 상관이 유의했으며, 자기애는 NPI 자기애 $(r=$ .62, $p<.001)$, Dirty Dozen_자기애 $(r=.54, p$ $<.001)$ 와의 상관이 유의한 것으로 나타났다.

\section{준거 타당도}

$\mathrm{SD} 2$ 척도의 준거 관련 타당도를 검증하기 위하여 다양한 준거변인들과의 상관분석을 실 시하였고, 그 결과를 표 6에 제시하였다. 우선 
Table 5. Convergent validities of SD2 $(N=250)$

\begin{tabular}{|c|c|c|c|c|}
\hline & & Total SD2 & $\begin{array}{c}\text { Machiavellianism } \\
\text {-Psychopathy(Ma-Psy) }\end{array}$ & Narcissism \\
\hline \multicolumn{2}{|c|}{ MPS_Machiavellianism } & $.70^{* * * *}$ & $.75^{* * *}$ & $.29^{* * * *}$ \\
\hline \multicolumn{2}{|c|}{ NPI_Narcissism } & $.43^{* * * *}$ & $.26^{* * * *}$ & $.62^{* * * *}$ \\
\hline \multicolumn{2}{|c|}{ SRPS_Psychopathy } & $.59^{* * * *}$ & $.61^{* * * *}$ & $.30^{* * * *}$ \\
\hline \multirow{3}{*}{ Dirty Dozen } & Machiavellianism & $.64^{* * *}$ & $.61^{* * * *}$ & $.44^{* * *}$ \\
\hline & Narcissism & $.48^{* * *}$ & $.36^{* * *}$ & $.54^{* * *}$ \\
\hline & Psychopathy & $.50^{* * * *}$ & $.50^{* * * *}$ & $.28^{* * * *}$ \\
\hline
\end{tabular}

${ }^{* * * *} p<.001$.

Table 6. Results of critrion validity of the SD2 $(N=250)$

\begin{tabular}{|c|c|c|c|c|}
\hline & & Total SD2 & $\begin{array}{c}\text { Machiavellianism } \\
\text {-Psychopathy(Ma-Psy) }\end{array}$ & Narcissism \\
\hline \multirow{8}{*}{$\begin{array}{c}\text { Interpersonal } \\
\text { Problems Circumplex } \\
\text { (대인관계문제) }\end{array}$} & $\begin{array}{l}\text { Unassured Submissive } \\
\text { (비주장성) }\end{array}$ & $.13^{*}$ & $.25^{* * *}$ & $-.19^{* * *}$ \\
\hline & $\begin{array}{l}\text { Unassuming Ingenuous } \\
\text { (과순응성) }\end{array}$ & $.25^{* * *}$ & $.31^{* * *}$ & .01 \\
\hline & $\begin{array}{l}\text { Warm Agreeable } \\
\text { (자기희생) }\end{array}$ & $.28^{* * *}$ & $.31^{* * *}$ & .08 \\
\hline & $\begin{array}{l}\text { Assured Dmonant } \\
\text { (통제지배) }\end{array}$ & $.63^{* * *}$ & $.63^{* * *}$ & $.37^{* * *}$ \\
\hline & $\begin{array}{l}\text { Arrogant Calculating } \\
\text { (자기중심) }\end{array}$ & $.40^{* * *}$ & $.49^{* * *}$ & .06 \\
\hline & $\begin{array}{l}\text { Gregarious Extraveted } \\
\text { (과관여) }\end{array}$ & $.61^{* * * *}$ & $.57^{* * * *}$ & $.44^{* * * *}$ \\
\hline & $\begin{array}{l}\text { Cold Hearted } \\
\text { (냉담) }\end{array}$ & $.26^{* * *}$ & $.40^{* * * *}$ & $-.14^{*}$ \\
\hline & $\begin{array}{l}\text { Avoid Introverted } \\
\text { (사회적 억제) }\end{array}$ & $.23^{* * *}$ & $.39^{* * *}$ & $-.20^{* * *}$ \\
\hline \multicolumn{2}{|c|}{ Somatization(신체화) } & $.30^{* * *}$ & $.31^{* * * *}$ & $.14^{*}$ \\
\hline \multicolumn{2}{|c|}{ Depression(우울) } & $.27^{* * *}$ & $.37^{* * * *}$ & -.05 \\
\hline \multicolumn{2}{|c|}{ Anxiety(불안) } & $.29^{* * * *}$ & $.36^{* * *}$ & .01 \\
\hline \multicolumn{2}{|c|}{ Attachment_Anxirty(애착_불안) } & $.38^{* * * *}$ & $.42^{* * * *}$ & $.13^{*}$ \\
\hline \multicolumn{2}{|c|}{ Attachment_Avoidance(애착_회피) } & .03 & .11 & $-.16^{*}$ \\
\hline \multicolumn{2}{|c|}{ Self-esteem(자존감) } & $.35^{* * *}$ & $.37^{* * *}$ & $.16^{*}$ \\
\hline
\end{tabular}

${ }^{*} p<.05,{ }^{* *} p<.01,{ }^{* * *} p<.001$. 
전체 $\mathrm{SD} 2$ 의 경우 애착회피를 제외한 나머지 변인들과의 정적 상관이 유의하였으며 $(r s=$ $.13 \sim .63, p<.05)$, 마찬가지로 하위 요인 중 사이코패스는 애착회피를 제외한 나머지 변인 들과의 정적 상관이 통계적으로 유의하였다(ts $=.25 \sim .63, p<.001)$. 반면 자기애는 통제 지배 $(r=.37, p<.001)$, 과관여 $(r=.44, p<$ $.001)$, 신체화 $(r=.14, p<.05)$, 애착불안 $(r=$ $.13, p<.05)$, 자존감 $(r=.16, p<.05)$ 과의 정 적 상관이, 비주장성 $(r=-.19, p<.001)$, 냉담 $(r=-.14, p<.05)$, 사회적 억제 $(r=-.20, p<$ $.01)$, 애착회피 $(r=-.16, p<.05)$ 와는 부적 상 관이 유의하였다. 이러한 결과는 사이코패스 와 자기애가 $\mathrm{SD} 2$ 의 하위 요인이지만, 준거 변 인들과의 관계에서 차별적으로 기능하고 있음 을 보여준다.

추가로, 직장인 및 자영업자만을 대상으로 $\mathrm{SD} 2$ 척도와 준거변인 간 상관분석을 실시한 결과, 전체 대상자와의 상관분석과는 다르게 자기애는 냉담 $(r=-.11, p>.05)$, 신체화 $(r=$ $.14, p>.05)$ 와는 상관이 유의하지 않았다.

\section{검사-재검사 신뢰도}

$\mathrm{SD} 3$ 척도의 검사-재검사 신뢰도를 살펴보기 위하여 연구 2 의 연구참여자 중 52 명에 대해 1 개월 간의 시간 간격을 두고 반복 측정한 점 수들 간 상관분석을 실시하였다. 그 결과, 전 체 $\mathrm{SD} 3$ 의 검사-재검사 신뢰도 $(f)$ 는 .77 , 하위 요인인 마키아벨리즘-사이코패스(Ma-Psy)와 자 기애는 각각 $.78, .79$ 로 시간에 따른 높은 안정 성을 보였다.

\section{논 의}

한국판 $\mathrm{SD} 3$ 의 확인적 요인분석 결과, 요인 부하량이 낮게 나온 자기애 17번 문항이 제거 되었는데, 이는 이 문항이 유일한 역채점 문 항이고 남들과 다른 것을 선호하지 않는 한국 사회의 집단주의 문화의 영향(Hofstede, 1980)으 로인해, 평범함을 반영하는 17 번 문항의 요인 부하량이 낮게 나왔을 가능성이 있다. 그 결 과, 한국판 $\mathrm{SD} 3$ 는 2 요인 구조인 $\mathrm{SD} 2$ 임을 확인 하였고 마키아벨리즘-사이코패스(Ma-Psy) 12문 항, 자기애 5 문항, 총 17 문항으로 확정 되었다. 문항 반응 이론을 토대로 적절성을 검토했을 때, 탐색적 요인분석의 결과 자기애에 관한 문항이 5 개로 줄어들어, 자기애가 낮은 응답 자들을 위한 문항이 적어진 점을 제외하고는 모든 문항이 적절한 것으로 나타났다.

한국판 SD2의 수렴타당도를 확인하기 위해 Dirty Dozen 척도(Jonason \& Webster, 2010), 한 국판 마키아벨리즘 척도(MPS; Kim 등, 2011), 한국판 자기애 성격검사(NPI; Han, 1999), 정신 병질 자기보고검사(SRPS; Lee \& Kim, 2011)를 사용하여 상관관계를 살펴본 결과 전반적으로 $\mathrm{SD} 2$ 의 하위요인과 유의한 정적 상관을 보였 다. 자기애는 Dirty Dozen의 자기애, NPI와 중 간 정도의 정적 상관을 보였으며 마키아벨리 즘-사이코패스(Ma-Psy)는 MPS와는 강한 정적 상관, SRPS, Dirty Dozen의 마키아벨리즘, Dirty Dozen의 사이코패스와는 중간 정도의 정적상 관을 보였다. 이 결과들은 간접적으로 한국판 $\mathrm{SD} 2$ 요인 구조의 변별 타당도를 지지하는 것 으로 2요인 구조를 제안한 선행연구(Persson et al., 2019; Vize et al., 2018)의 타당성을 확인하 는 결과이다.

다음으로 한국판 $\mathrm{SD} 2$ 의 준거 타당도를 검 
증하기 위하여 대인관계문제, 심리적 증상(신 체화, 우울, 불안), 애착, 자존감과의 상관관계 를 살펴보았다. 먼저, 대인관계문제와 관련하 여 마키아벨리즘-사이코패스(Ma-Psy) 요인은 모두 정적 상관이 유의하였다. 이는 어두운 성격의 높은 점수가 대인관계문제와 관련이 있고, 특히 마키아벨리즘과 사이코패스 점수 가 높은 경우 대인관계에서 냉담하며, 타인을 불신하고 공감 능력이 부족해 타인의 필요와 행복에 관심을 기울이지 못하는 특징을 설명 한 선행연구(Dowgwillo \& Pincus, 2016) 결과와 비슷한 맥락이다.

한편, 자기애는 대인관계문제의 하위 요인 중 과순응성, 자기희생, 자기중심과는 통계적 으로 유의한 상관을 보이지 않았다. 반면 비 주장성, 냉담, 사회적 억제와는 부적 상관을, 그리고 통제지배 및 과(過)관여와는 정적 상관 을 보였다. 이는 자기애가 대인관계문제에서 통제 및 지배와 정적 상관이 있고, 비주장성 과 부적 상관이 있다는 Given-Wilson과 동료들 (2011)의 연구 결과와도 일치한다. 이는 대인 관계 문제에서 $\mathrm{SD} 2$ 의 마키아벨리즘-사이코패 스(Ma-Psy)와 자기애 성향을 보이는 사람들이 비주장성, 냉담, 사회적 억제 수준에서 차이를 보이므로, 총점이 같더라도 자기애 성향이 우 세한 사람들은 마키아벨리즘-사이코패스 성향 이 우세한 사람들과 달리 대인관계에서 자기 주장과 정서표현이 더 적극적이며 타인 앞에 서 덜 당황하고 덜 불안해하는 경향에서 차이 가 있음을 의미한다.

심리학적 증상과의 관계에서 신체화는 모두 정적 상관을 보였으나, 우울, 불안은 마키아벨 리즘-사이코패스(Ma-Psy)와만 정적 상관을 보 였다. 이는 우울 및 불안이 마키아벨리즘, 사 이코패스와는 높은 상관을 보임과는 달리, 자
기애와는 낮은 상관을 보여준 선행연구 결과 (Sabouri et al., 2016; Shih et al.,, 2019)와 일치 한다. 또한 자기애가 더 높은 수준의 정신적 강인함으로 인해 우울 증상이 낮음을 보고한 연구 결과(Papageorgiou et al., 2019)와도 일치한 다. 마키아벨리즘-사이코패스(Ma-Psy)는 자기애 와 달리 우울, 불안과 정적 상관을 보였다. $\mathrm{BSI}-18$ 의 우울 요인은 절망감, 무쾌감, 자기비 하, 불쾌한 기분과 연관되며(Park 등, 2012), 사 이코패스적 경향이 큰 사람들은 지속적으로 반사회적인 특성과 공감을 잘하지 못하고 자 기중심적인 면으로 인해 대인관계에서 어려움 을 겪고, 안정적인 사회적 유능성을 느끼기 어려운 결과로 우울해질 수 있다(Kwon, 2016). 아울러, 불안은 염려, 안절부절 못함, 긴장, 신 경질적인 증상을 포함하는데(Park 등, 2012), 마키아벨리즘-사이코패스(Ma-Psy)적 경향이 큰 사람들은 자신의 이익을 위해 타인과 전략적 인 동맹을 구축하고자 하지만, 장기적인 상호 작용을 할 때 도덕성과 공감 능력이 결여된 특징으로 인해 뜻한 대로 우호적인 동맹관계 를 형성하는 데 실패하게 되면 사회적 불안이 유발될 수 있다.

애착과 관련하여 애착불안은 마키아벨리즘사이코패스(Ma-Psy), 자기애와 정적 상관을 보 였으며, 애착회피는 자기애와 부적 상관을 나 타냈다. 이는 Brewer 등(2018)의 연구에서 사이 코패스와 자기애는 애착불안을 예측한다는 점 과 일치하는 결과이다. $\mathrm{SD} 2$ 에서의 마키아벨리 즘-사이코패스(Ma-Psy)와 자기애는 어린 시절 부모로부터 사랑을 받지 못하고 불안에 대처 할 수 있는 안전기지의 경험을 하지 못한 측 면을 반영한다. 이러한 경험은 애착 욕구를 충족시켜줄 중요한 타인의 유익함을 경험하지 못해 현재 관계를 맺고 있는 사람들과의 관계 
에서도 불안을 느껴(Wallin, 2007) 애착불안과 정적 상관을 보였을 가능성이 있다. 반면 애 착회피는 자기애하고만 부적 상관을 보였는데, 이는 타인과 관계 속에서 거리를 두기보다는, 과장된 방식으로 자신에게 이목을 집중시켜 우월함만을 표현하고 싶어 하는 자기애 성향 을 지닌 사람들의 특성을 반영하는 것으로 볼 수 있다.

다만 자신에 대한 긍정적이거나 부정적인 지향성으로서 자신의 가치에 대한 총체적인 평가인 자존감(Lee \& Won, 1995)의 경우 마키 아벨리즘-사이코패스(Ma-Psy)와 자기애 둘 다 약한 상관을 보여 $\mathrm{SD} 2$ 의 하위 요인 간 변별력 있는 차이를 발견하지 못하였다.

요약하면, 변별타당도를 검증을 위한 각각 변인과의 상관을 종합할 때 대인관계문제의 하위요인 중 비주장성, 통제지배, 사회적 억제 에서는 마키아벨리즘-사이코패스(Ma-Psy)가 정 적 상관을 자기애는 부적 상관을 보였고, 심 리학적 증상 중 우울, 불안에서는 마키아벨리 즘-사이코패스(Ma-Psy)의 관계에서만 정적 상 관이 나타났으며, 애착회피에서는 자기애의 관계에서만 부적 상관으로 나타났다. 이러한 차이로 볼 때 마키아벨리즘-사이코패스(Ma-Psy) 와 자기애가 명확하게 구분되는 요인임을 다 시 확인할 수 있었다. 이는 $\mathrm{SD} 2$ 를 활용한 추 후 연구에서 $\mathrm{SD} 2$ 의 전체 점수로 접근하기보 다, 하위 요인의 특성을 구분하여 접근하는 것이 바람직함을 시사한다.

\section{종합논의}

본 연구의 주요 결과 및 의의는 다음과 같 다. 먼저, 한국판 $\mathrm{SD} 3$ 는 원척도의 3 요인 구조
(Johns \& Paulhus, 2014)의 결과와는 달리 어두 운 성격의 2 요인 구조(SD2)의 결과가 나타났 다. 구체적으로 자기애는 다른 어두운 성격과 는 구별되는 고유한 특성을 가지며, 사이코패 스와 마키아벨리즘은 하나의 요인으로 구성됨 을 확인하였다. 이러한 연구결과는 선행연구 결과(Persson et al., 2019; Vize et al., 2018)를 지 지하는 것으로 한국 문화에서 어두운 성격의 특징은 2요인 구조로 보다 명확히 설명될 수 있음을 시사한다. 본 연구 결과, 한국에서는 어두운 성격 요소 중 사이코패스와 마키아벨 리즘 간의 구별이 어려웠다. 이 둘이 혼합된 마키아벨리즘-사이코패스(Ma-Psy)와 관련된 문 항이 원척도에서는 18 문항이었으나 본 연구에 서는 탐색적 요인분석과 확인적 요인분석을 거치면서 12 문항으로 단축되었다. 특히 사이 코패스에 관한 문항들이 마키아벨리즘에 관한 문항들과 비교할 때 3 문항이 더 감소한 점과 Persson 등(2019)의 연구에서 사이코패스 문항 은 마키아벨리즘 요인에 부하된다는 점으로 미루어 보아, SD2의 마키아벨리즘-사이코패스 (Ma-Psy) 하위 차원은 비임상적 사이코패스인 마키아벨리즘의 성향을 많이 포함하고 있는 것으로 보인다. 사이코패스를 측정하는 문항 은 '나는 보복은 빠르게 이루어져야 하고 심 술궂을 필요가 있다고 생각한다,' '나는 다른 사람에게 못되게 굴 수 있다.와 같이 마키아 벨리즘에서 나타나는 특성인 냉담함보다 다소 더 냉정한 수준의 감정을 함께 측정할 수 있 다는 점에서 마키아벨리즘의 특성만을 측정하 고 있는 K-MPS와는 구별된다. 요컨대 본 연구 의 한국판 $\mathrm{SD} 2$ 는 마키아벨리즘-사이코패스 (Ma-Psy) 12문항, 자기애 5문항의 총 17문항 2 요인 구조로 최종 구성되었고 자기애가 사이 코패스, 마키아벨리즘과 구별되는 개념임을 
재확인했다는 점과 단일 척도로 마키아벨리즘 -사이코패스(Ma-Psy)와 자기애를 측정할 수 있 다는데 의의가 있다.

둘째, 본 연구에서 $\mathrm{SD} 2$ 문항들의 적절성을 평가하기 위해 각 요인별로 Rasch모형을 적용 하였는데, 이는 Rasch 모형의 기본 전제가 단 일요인이어야 한다는 조건(Hong \& Cho, 2006) 을 충족하기 위함이었다. 한국판 $\mathrm{SD} 2$ 는 두 요 인의 응답범주 측면에서 5 점 척도가 적절함을 밝혔다. 또한 각 문항의 피험자 응답반응이 얼마나 문항반응이론 모형에 적절한지를 확인 하여 문항을 선별하는 문항적합도를 분석한 결과, 한국판 $\mathrm{SD} 2$ 의 최종 17 개 문항만으로도 어두운 성격에 대한 타당한 측정이 가능하다 는 점이 확인되었다. 원척도에서 수정된 $\mathrm{SD} 2$ 는 문항 수가 원척도의 $70 \%$ 정도밖에 안 되 면서도 문항의 적절성과 타당성 측면에서 우 수한 문항만을 선별한 것이기 때문에 향후 한국에서 어두운 성격을 측정할 때 효용성이 있다.

셋째, 한국판 SD2의 수렴 및 준거 타당도를 확인하기 위해 기존의 어두운 성격과 관련된 변인들과의 수렴타당도를 확인하였는데 전반 적으로 예상된 방향으로 유의한 정적 상관이 나타났다. 이는 한국판 $\mathrm{SD} 2$ 의 수렴타당도를 지지하는 결과이다. 다음으로 변별타당도를 확인하기 위해 대인관계문제, 우울, 불안, 신 체화, 성인애착과의 관계를 살펴보았다. 그 결과, 대인관계에서 마키아벨리즘-사이코패스 (Ma-Psy)차원은 타인을 통제하려는 특성과 친 밀함을 보이지 않으려는 성향을 보인 반면 자 기애 차원의 경우는 타인에게 흥미나 관심을 보여 친밀감을 유지하려는 성향을 보였다. 이 는 자기애가 타인에게 다가가는 것에 대한 두 려움이 적어 마키아벨리즘-사이코패스(Ma-Psy)
보다는 친밀한 대인관계를 보이고 따라서 대 인관계에서 오는 우울감과 불안감이 적은 것 으로 해석할 수 있다. 전반적으로 변별 타당 도 분석 결과는 한국판 $\mathrm{SD} 2$ 의 마키아벨리즘사이코패스(Ma-Psy) 차원과 자기애 차원은 서 로 차별적으로 기능하는 어두운 성격의 요소 로 볼 수 있다.

본 연구 참여자 중 직장인 및 자영업자만을 대상으로 $\mathrm{SD} 2$ 척도와 준거 변인 간 상관분석 을 한 결과, 자기애는 대인관계문제의 하위 척도인 냉담, 신체화와 상관이 유의하지 않았 다. 이는 연구참여자 전체를 대상으로 했을 때 자기애와 냉담 간 부적 상관이 유의하고, 신체화와 정적 상관은 유의했던 결과와 차이 가 있다. 우선, 냉담은 정서의 경험 및 표현에 대한 문제를 측정하는데, 자기애 성향이 높은 직장인이 동료, 부하직원, 상사와의 갈등을 피 하고 부정정서 표현을 조절하여 조직몰입도 및 직무만족도에 긍정적 효과가 있다는 연구 결과(Rie, 2003)로 미루어 볼 때, 자기애 성향 이 높은 경우 직장 내에서 대인관계를 손상시 키지 않는 수준으로 정서를 표현하는 의사소 통 방식을 사용하고 있을 가능성이 있다. 유 사하게, 직장인 및 자영업 대상으로 했을 때 자기애와 신체화가 유의하지 않았던 것을 정 서 표현과 관련지어 볼 수도 있다. 신체화는 한국의 문화 정서 규범에 적절한 간접적인 정 서표현방식(Kim, 2002)이라는 점에서, 자기애 성향이 직장 내에서 보다 직접적인 정서표현 방식으로 나타날 가능성을 시사한다. 다만, 본 연구는 조직행동 및 조직맥락 변인과의 관련 성을 실증적으로 파악한 것은 아니므로, 조심 스럽게 해석할 필요가 있으며 추후 후속 연구 로 구체적으로 밝힐 필요가 있다.

반면 본 연구에서 $\mathrm{SD} 3$ 원척도의 3 요인 구 
조가 나타나지 않은 점을 해석할 때 이 결과 가 본 연구에서 비임상군을 연구대상으로 한 결과 때문일 가능성을 배제할 수 없다는 점, 그리고 어두운 성격 역시 나이가 들어감에 따 라 그 강도가 약화될 수 있다는 점이 어떤 영 향을 주었는지에 대해서는 확인하지 못했다는 한계가 있다. 관련해서 한국판 $\mathrm{SD} 2$ 를 연구나 상담 에서 사용할 때 임상적으로 유의미하게 점수가 높은 집단과 낮은 집단을 구분하는 절 단점(cut off)을 제공하지 못한 점과 특정 점수 의 의미를 해석할 수 있는 규준(norm)을 제공 하지 못한 점도 한계점이라고 할 수 있다.

본 연구의 조사 대상이 직장인뿐 아니라, 학생, 주부, 무직 등 $(18 \%)$ 이 포함되어 있어 직 장인만을 대상으로 하여 요인구조 차별성의 확인에는 한계가 있어, 후속 연구에서는 조직 맥락에서 검증을 하기 위해 다양한 직군의 직 장인만을 대상으로 $\mathrm{SD} 2$ 요인구조의 차별성을 확인하고 종단 연구를 통해 두 요인 점수들이 변화하는지도 함께 확인할 필요가 있다. 본 연구에서 SD-2의 마키아벨리즘-사이코패스 (Ma-Psy)차원의 조직내 대인관계 패턴 및 조직 성과 등과 관련된 변수들과의 관계를 살핌으 로써 마키아벨리즘-사이코패스(Ma-Psy)차원의 특징 및 준거타당도 검증을 위해 포함된 변인 들 외에 특히 최근 갑질 문제가 사회적 논란 이 되고 있는 현실에서 어두운 성격특성을 가 진 사람들의 분노, 분노표현양식, 공격성, 전 위공격성 등의 변인과의 관계에 대해 살펴볼 필요가 있다.

이러한 한계점에도 불구하고 본 연구를 통 해 SD2를 한국에서 번안 - 타당화 함으로써 추 후 한국인의 어두운 성격 관련 연구 및 어두 운 성격의 조직내 파괴적 행동(예: 비생산적 업무 행동, 학대적 감독 등), 대인관계 패턴과
조직성과에 미치는 영향에 대한 연구를 할 수 있는 도구를 제공했다는 데 의의가 있다.

\section{참고문헌}

Ahn, S. Y., \& Kim, J. H. (2016). The influence of self camera(selfie) on self-disclosure, body-esteem, appearance management, social self-efficacy of women in their 20s: Focused on proteus effect. Cybercommunication Academic Society, 33(2), 87-123.

Andrich, D. (1978). Rating formulation for ordered response categories. Psychometrika, 43, 561-573. American Psychiatric Association. (2013). Diagnostic and statistical manual of mental disorders (DSM-5). American Psychiatric Pub.

Arseneault, R., \& Catano, V. (2019). An extension of the dark triad and five factor model to three Asian societies. Asian Journal of Social Psychology, 22(4), 358-368.

http://doi.org/10.1111/ajsp.12378

Back, M. D., Kufner, A. C. P., Dufner, M., Gerlach, T. M., Rauthmann, J. F., \& Denissen, J. J. A. (2013). Narcissistic admiration and rivalry: Disentangling the bright and dark sides of narcissism. Journal of Personality and Social Psychology, 105, 10131037. http://doi.org./10.1037/a0034431

Baviak, P. (1995). When psychopaths go to work: A case study of an industrial psychopath. Applied Psychology, 44(2), 171-188.

Brennan, K. A., Clark, C. L., \& Shaver, P. R. (1998). Self-report measurement of adult attachment: An integrative overview. In J. A. 
Simpson \& W. S. Rholes (Eds.), Attachment theory and close relationships (pp. 46-76). New York: Guilford Press.

Brewer, G., Bennett, C., Davidson, L., Ireen, A., Phipps, AJ., Stewart-Wilkes, D., \& Wilson, B. (2018). Dark triad traits and romantic relationship attachment, accommodation, and control. Personality and Individual Differences, 120, 202-208. http://doi.org./808010.1016

Campbell, W. K., \& Miller, J. D. (2011). The handbook of narcissism and narcissistic personality disorder: Theoretical approaches, empirical findings, and treatments. John Wiley \& Sons.

Cho, S-H (2017). Polarization of internships and the government guidelines for intern protection. The Journal of Labor Law, 40, 395-444.

Christie, R., \& Geis, F. L. (1970). Chapter I Why Machiavelli?. Studies in Machiavellianism, $1-9$.

Cho, H, J. \& Seo, Y. S. (2011). Adult attachment and psychological distress: Mediating roles of maladaptive perfectionism and basic psychological needs satisfaction. Korean Journal Of Counseling And Psychotherapy, 23(2), 471490.

Cleckley, H. (1941). The mask of sanity. Oxford, England: Mosby.

Cohen, A. (2016). Are they among us? A conceptual framework of the relationship between the dark triad personality and counterproductive work behaviors (CWBs). Human Resource Management Review, 26(1), 69-85.

https://doi.org/10.1016/j.hrmr.2015.07.003
Costello, A. B., \& Osborne, J. (2005). Best practices in exploratory factor analysis: Four recommendations for getting the most from your analysis. Practical Assessment, Research \& Evaluation, 10, 1-9. https://doi.org/10.7275/jyj1-4868

Dahling, J. J., Whitaker, B. G., \& Levy, P. E. (2009). The development and validation of a new Machiavellianism scale. Journal of Management, 35(2), 219-257. http://doi.org./10.1177

Derogatis, L. R. (2001). Brief Symptom Inventory (BSI)-18. Administration, scoring and procedures manual. Minneapolis: NCS Pearson, Inc.

Dowgwillo, E. A., \& Pincus, A. L. (2016). Differentiating dark triad traits within and across interpersonal circumplex surfaces. Research Article, 24(1), 24-44. http://doi.org./10.1177/1073191116643161

Fraley, R. C., Brennan, K. G., \& Waller, N. G. (2000). An item response theory analysis of self-report measures of adult attachment. Journal of Personality and Social Psychology, $78(2), 350-365$ http://doi.org./10.1037/0022-3514.78.2.350

Furnham, A., Richards, S. C., \& Paulhus, D. L. (2013). The Dark Triad of personality: A 10 year review. Social and Personality Psychology Compass, 7(3), 199-216. http://doi.org/10.1111/spc3.12018

Gamache, D., Savard, C., \& Maheux-Caron, V. (2018). French adaptation of the Short Dark Triad: Psychometric properties and a head-to-head comparison with the Dirty 
Dozen. Personality and Individual Differences, 122, 164-170.

http://doi.org./10.1016/j.paid.2017.10.027

Gebauer, J. E., Sedikides, C., Verplanken, B., \& Maio, G. R. (2012). Communal narcissism. Journal of Personality and Social Psychology, 103(5), 854-878.

http://doi.org./10.1037/a0029629

Geng, Y. G., Sun, Q, B., Huang, J. Y., Zhu, Y. Z., \& Han, X. H. (2015). Dirty Dozen and Short Dark Triad: A Chinese validation of two brief measures of the Dark Triad. Chinese Journal of Clinical Psychology, 23, 246-250.

Given-Wilson, Z., Mcllwain, D., \& Warburton, W. (2011). Meta-cognitive and interpersonal difficulties in overt and covert narcissism. Personality and Individual Differences, 507), 1000-1005.

http://doi.org./10.1016/j.paid.2011.01.014

Han, S. J. (1999). Overt and covert self-relevant cognition of narcissists. Unpublished doctoral dissertation. Seoul National University, Seoul, Korea

Hare, R. D., \& Neumann, C. S. (2008). Psychopathy as a clinical and empirical construct. Annual Review of Psychology, 4, 217-246.

https://doi.org/10.1146/annurev.clinpsy.3.022806 .091452

Hofstede, G. (1980). Culture and organizations. International Studies of Management \& Organization, 10(4), 15-41.

Homg, S. H. (2000). The criteria for selecting appropriate fit indices in structural equation modeling and their rationales. Korean Journal of
Clinical Psychology, 19(1), 161-177.

Homg, S. H., \& Cho, Y. R. (2016). Construction of a short version of the dysfunctional beliefs test: An application of Rasch rating scale model. Korean Journal of Clinical Psychology, 23(3), 865-880.

Hong, S., Kim, B., \& Wolfe, M. (2005). A psychometric revision of the European American Values Scale for Asian Americans using the Rasch Model. Measurement and Evaluation in Counseling and Development, 37, 194-207. http://doi.org./10.1080/07481756.2005.1190976 0

Horowitz, L. M., Rosenberg, S. E., Baer, B. A., Ureno, G., \& Villasenor, V. S. (1988). Inventory of interpersonal problems: psychometric properties and clinical applications. Journal of Consulting and Clinical Psychology, 566), 885-892. http://doi.org./10.1037/0022-006X.56.6.885

Howard, M. C. (2016). A review of exploratory factor analysis decisions and overview of current practices: What we are doing and how canwo improve? International Journal of Human-Computer Interaction, 32(1), 51-62. https://doi.org/10.1080/10447318.2015.1087664

Hu, L. T., \& Bentler, P. M. (1999). Cutoff criteria for fit indexes in covariance structure analysis: Conventional criteria versus new alternatives. Structural Equation Modeling, 6, 1-55. http://doi.org./10.1080/10705519909540118

Jeong, H-W. \& Jo, G-W. (2019). An empirical study on 'Gapjil' culture in korean society. Korean Political Science Review, 53(1), 105-125. 
Jonason, P. K., Kavanagh, P. S., Webster, G. D., \& Fitzgerald, D. (2011). Comparing the measured and latent dark triad: Are three measures better than one?. Journal of Methods and Measurement in the Social Sciences, 2(1), 28-44. http://dx.doi.org/10.2458/v2i1.12363

Jonason, P. K., \& Webster, G. D. (2010). The dirty dozen: a concise measure of the dark triad. Psychological Assessment, 22(2), 420-432. http://doi.org./10.1037/a0019265

Jones, D. N., \& Paulhus, D. L. (2011). The role of impulsivity in the Dark Triad of personality. Personality and Individual Differences, 51(5), 679-682.

https://doi.org/10.1016/j.paid.2011.04.011

Jones, D. N., \& Paulhus, D. L. (2014). Introducing the short dark triad (SD3) a brief measure of dark personality traits. Assessment, 21(1), 28-41.

https://doi.org/10.1177/1073191113514105

Kajonius, P. J., Persson, B. N., Rosenberg, P., \& Garcia, D. (2016). The (mis) measurement of the Dark Triad Dirty Dozen: exploitation at the core of the scale. PeerJ, 4, e1748.

Kim, H. S., Hong, G. H., \& Hyun, M. H. (2011). Validity and reliability of the Korean version of the machiavellianism personality scale(K-MPS). Stress, 191), 21-30

Kim, S. H. (2004). Adaptation of the experiences in close relationships-revised scale into korean: Confirmatory factor analysis and item response theory approaches. Unpublished master's thesis. Seoul National University, Seoul, Korea

Kim, T. H. (2009). Psychopath and Narcissist. Seoul: Saechangmedia.
Kim, Y (2002). The mediating effect of cultural variables on somatization. [Doctoral dissertation, Korea University].

Kwon, S. M. (2016). Depression: A swamp of depression and despair. Seoul: Hakjisa

Lee, H-J., \& Won, H. T. (1995). Self-concepts and paranoid tendency. Psychological Science, 4, 15-29.

Lee, S. J., \& Kim, J. K. (2011). The study of validity on the self-report psychopathy scale(SRPS). Korean Journal of Psychology: Law, 2(1), 35-47.

Lee, Y. S., Homg, S. H., \& Shin, E. K.(2007). Rasch rating scale modeling of the disability identity scale. Korean Journal of Social Welfare, 594), 273-296.

Levenson, M. R., Kiehl, K. A., \& Fitzpatrick, C. M. (1995). Assessing psychopathic attributes in a noninstitutionalized population. Journal of Personality and Social Psychology, 68(1), 151-158. https://doi.org/10.1037/0022-3514.68.1.151

Levy, K. L., Ellison, W. D., \& Reynoso, J. S. (2012). A historical review of narcissism and narcissistic personality. In J. D. Miller \& K. W. Campbell (Eds.), The handbook of narcissism and narcissistic personality disorder: Theoretical approaches, empirical findings, and treatments (pp. 1-13). Hoboken, NJ: Wiley.

Lilienfeld, S. O., \& Andrews, B. P. (1996). Development and preliminary validation of a self-report measure of psychopathic personality traits in noncriminal population. Journal of Personality Assessment, 66(3), 488-524. https://doi.org/10.1207/s15327752jpa6603_3

Linacre, J. M. (2005). WINSTEPS Rasch measurement 
[computer software]. Chicago, IL: Winsteps.com. Linacre, J. M. (2011). A user's guide to WINSTEPS MINISTEP Rasch-model computer programs. http://www.winsteps.com.

Lorenzo-Seva, U \& Ferrando, P. J. (2015). FACTOR 10.3 [computer software]. University of Rovira i Virgili, Spain.

Lykken, D. T. (1995). The antisocial personalities. Hillsdale, New Jersey: Lawrence Earlbaum Associates. Inc.

Lyons, M. (2019). The Dark Triad of Personality:

Narcissism, machiavellianism, and psychopathy in everyday life. Academic Press.

Mahmut, M. K., Menictas, C., Stevenson, R. J., \& Homewood, J. (2011). Validating the factor structure of the Self-Report Psychopathy scale in a community sample. Psychological Assessment, 23(3), 670-678.

https://doi.org/10.1037/a0023090

Malesza, M., Ostaszewski, P., Buchner, S., \& Kaczmarek, M. C. (2019). The adaptation of the Short Dark Triad personality measurepsychometric properties of a German sample. Current Psychology, 38(3), 855-864. https://doi.org/10.1007/s12144-017-9662-0

Miller, J. D., Few, L. R., Seibert, L. A., Watts, A., Zeichner, A., \& Lynam, D. R. (2012). An examination of the Dirty Dozen measure of psychopathy: A cautionary tale about the costs of brief measures. Psychological Assessment, 24(4), 1048-1053.

Miller, J. D., Lynam, D. R., \& Campbell, W. K. (2016). Measures of narcissism and their relations to DSM.5 pathological traits: A critical reappraisal. Assessment, 23, 3-9.
Myung, J. K, (2016). Effects of CEOs' negative traits on corporate social responsibility: Focusing on the mediating impacts of organization's perceived role of ethics and social responsibility. Unpublished doctoral dissertation. Inha University, Incheon, Korea.

O'Boyle, E. H., Forsyth, D. R., Banks, G. C., Story, P. A., \& White, C. D. (2015). A meta-analytic test of redundancy and relative importance of the dark triad and five-factor model of personality. Journal of personality, 83(6), 644-664. http://doi.org/10.1111/jopy.12126

Ozsoy, E., Rauthmann, J. F., Jonason, P. K., \& Ardıc, K. (2017). Reliability and validity of the Turkish versions of dark triad dirty dozen (DTDD-T), short dark triad (SD3-T), and single item narcissism scale (SINS-T). Personality and Individual Differences, 117, 11-14. https://doi.org/10.1016/j.paid.2017.05.019

Papageorgiou, K. A., Denovan, A., \& Dagnall, N. (2019). The positive effect of narcissism on depressive symptoms through mental toughness: Narcissism may be a dark trait but it does help with seeing the world less grey. European Psychiatry, 55, 74-79.

Park, K. P., Woo, S. W., \& Chang, M. S. (2012). Validational study of brief symptoms inventory-18(BSI-18) in college students. Korean Journal of Clinical Psychology, 31(2), 507-521

Paulhus, D. L., \& Jones, D. N. (2015). Measures of dark personalities. In G. J. Boyle, D. H. Saklofske, \& G. Matthews (Eds.), Measures of 
personality and social psychological constructs (pp. 562-594). San Diego, CA: Academic Press.

Paulhus, D. L., \& Williams, K. M. (2002). The dark triad of personality: Narcissism, Machiavellianism, and psychopathy. Journal of Research in Personality, 36(6), 556-563. https://doi.org/10.1016/S0092-6566(02)00505-6

Pechorro, P., Caramelo, V., Oliveira, J. P., Nunes, C., Curtis, S. R., \& Jones, D. N. (2019). The Short Dark Triad (SD3): Adaptation and psychometrics among at-risk male and female youths. Deviant Behavior, 40(3), 273-286.

https://doi.org/10.1080/01639625.2017.1421120

Persson, B. N., Kajonius, P. J., \& Garcia, D. (2019). Revisiting the structure of the Short Dark Triad. Assessment, 26(1), 3-16. https://doi.org/10.1177/1073191117701192

Poythress, N. G., \& Hall, J. R. (2011). Psychopathy and impulsivity reconsidered. Aggression and Violent Behavior, 16(2), 120-134. https://doi.org/10.1016/j.avb.2011.02.003

Preacher, K. J. \& MacCallum, R. C. (2003). Repairing Tom Swift's electric factor analysis machine. Understanding Statistics, 2(1), 13-43. https://doi.org/10.1207/S15328031US0201_02

Raskin, R., \& Hall, C. S. (1981). The Narcissistic Personality Inventory: Alternative form reliability and further evidence of construct validity. Journal of Personality Assessment, 45(2), 159-162. https://doi.org/10.1207/s15327752jpa4502_10

Rauthmann, J. F., \& Kolar, G. P. (2012). How "dark" are the Dark Triad traits? Examining the perceived darkness of narcissism, Machiavellianism, and psychopathy. Personality and Individual Differences, 53(7), 884-889.

https://doi.org/10.1016/j.paid.2012.06.020

Rauthmann, J. F. (2013). Investigating the $\mathrm{MACH}$ IV with item response theory and proposing the trimmed MACH. Journal of Personality Assessment, 95(4), 388-397. https://doi.org/10.1080/00223891.2012.742905

Rie, J. I. (2013). Anger, anxiety, depression in the workplace-Differences of evoking causes and coping methods among emotions, relationships of emotion regulation and psychological well-being, job effectiveness. Korean Journal of Industrial and Organizational Psychology, 16(3), 19-58.

Rogoza, R., \& Cieciuch, J. (2018). Dark Triad traits and their structure: An empirical approach. Current Psychology, 1-16. https://doi.org/10.1007/s12144-018-9834-6

Rosenberg, M. (1965). Society and adolescent self-image. Princeton, NJ: Princeton University Press.

Sabouri, S., Gerber, M., Lemola, S., Becker, S. P., Shamsi, M., Shakouri, Z., Bahmani, D. S., Kalak, N., Holsboer-Trachsler, E., \& Brand, S. (2016) Examining Dark Triad traits in relation to sleep disturbances, anxiety sensitivity and intolerance of uncertainty in young adults. Comprehensive Psychiatry, 68, 103-110.

https://doi.org/10.1016/j.comppsych.2016.03.012

Shih, S. I., Chi, N. W., Wu, C. C., \& Wang, S. Y. (2019). When dark meets blue: The relations between dark triad personality and depression symptoms. Current Psychology, 1-8. https://doi.org/10.1007/s12144-019-00549-7 
Spain, S. M., Harms, P., \& LeBreton, J. M. (2014). The dark side of personality at work. Journal of Organizational Behavior, 35, 41-60. http://doi.org/10.1002/job.1894

Spurk, D., \& Hirschi, A. (2018). The Dark Triad and competitive psychological climate at work: A model of reciprocal relationships in dependence of age and organization change. European Journal of Work and Organizational Psychology, 27(16), 736-751. https://doi.org/10.1080/1359432X.2018.151520 0

Tabachnick, B. G., \& Fidell, L. S. (1996). Using multivariate statistics (3rd ed.). New York: Harper Collins.

Teyber, E., \& Teyber, F. (2017). Interpersonal process in therapy: An integrative model. Cengage Learning: Boston.

Vize, C. E., Lynam, D. R., Collison, K. L., \& Miller, J. D. (2018). Differences among dark triad components: A meta-analytic investigation. Personality Disorders: Theory, Research, and Treatment, 9(2), 101-111. https://doi.org/10.1037/per0000222

Wallin, D. J. (2007). Attachment in psychotherapy. Guilford press.

Williams, K. M., Paulhus, D. L., \& Hare, R. D. (2007). Capturing the four-factor structure of psychopathy in college students via self-report. Journal of Personality Assessment, 88(2), 205-219. https://doi.org/10.1080/00223890701268074
Wright, B. D., \& Masters, G. N. (1982). Rating scale analysis. Chicago, IL: Measurement, Evaluation, Statistics, and Assessment Press.

Yang, J. E., Chang, M. S., So, J. H., \& Kwak, H. W. (2011). Emotion processing of people with psychopathic tendency. Korean Journal of Psychology: General, 30(2), 357-375.

Yildirim, B. O., \& Derksen, J. J. (2015). Clarifying the heterogeneity in psychopathic samples: Towards a new continuum of primary and secondary psychopathy. Aggression and Violent Behavior, 24, 9-41. https://doi.org/10.1016/j.avb.2015.05.001

Zeigler-Hill, V. E., \& Marcus, D. K. (2016). The dark side of personality: Science and practice in social, personality, and clinical psychology. Washington: American Psychological Association.
투고일자 : 2021. 03. 25 수정일자 : 2021. 06. 07 게재확정 : 2021. 08. 07 


\title{
Factor Structure and Validity Estimates of the Korean Version of the Short Dark Triad
}

\author{
Park, Chong Chol \\ Sohn, Harim
}

\author{
Oh, Hyunjoo \\ Lee, Dong-gwi \\ Yonsei University
}

\author{
Lee, Nahee
}

Bae, Byeong-hoon

\begin{abstract}
The present study aims to assess the psychometric properties (i.e., reliability and validity) and factor structure of the Korean version of the Short Dark Triad (SD3) with 27 items for evaluating the traits of the Dark Triad: narcissism, Machiavellianism, and psychopathy. An analysis of factor structure using both exploratory factor analysis (EFA) and confirmatory factor analysis (CFA) within Study 1 and Study 2 ( $N$ $=250$ for study $1, N=250$ for study 2) yielded two factors of Machivellianism-Psychopathy (Ma-Psy) and Narcissism in Korea and did not suport the 3-factor solution of the original SD3 developed by Johns \& Paulhus (2014). For item-level validity, the Rasch Rating Scale Model was applied and the final 17 items with two factors of the dark personality (SD-2) were confirmed as a result of an item goodness-of-fit and item difficulty. Also, the psychometric properties of the Korean adaptation of the SD3 (2-factor solution with 17 items, called SD2) provided support for both convergent and discrimiant validity estimates as well as stability over 1-month time interval. Implications and limitations of the current research are discussed.
\end{abstract}

Key words : Short Dark Triad, Narcissism, Machiavellianism, Psychopathy 